Atmos. Chem. Phys., 17, 13119-13138, 2017

https://doi.org/10.5194/acp-17-13119-2017

(C) Author(s) 2017. This work is distributed under

the Creative Commons Attribution 3.0 License.

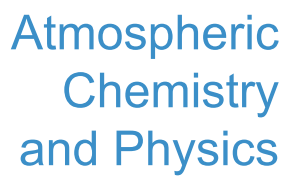

(c) (P)

\title{
Frequent ultrafine particle formation and growth in Canadian Arctic marine and coastal environments
}

\author{
Douglas B. Collins ${ }^{1}$, Julia Burkart ${ }^{1}$, Rachel Y.-W. Chang ${ }^{2}$, Martine Lizotte ${ }^{3}$, Aude Boivin-Rioux ${ }^{4}$, Marjolaine Blais ${ }^{4}$, \\ Emma L. Mungall ${ }^{1}$, Matthew Boyer ${ }^{2}$, Victoria E. Irish $^{5}$, Guillaume Massé ${ }^{3}$, Daniel Kunkel ${ }^{6}$, Jean-Éric Tremblay ${ }^{3}$, \\ Tim Papakyriakou ${ }^{7}$, Allan K. Bertram ${ }^{5}$, Heiko Bozem ${ }^{6}$, Michel Gosselin ${ }^{4}$, Maurice Levasseur ${ }^{3}$, and \\ Jonathan P. D. Abbatt ${ }^{1}$ \\ ${ }^{1}$ Department of Chemistry, University of Toronto, Toronto, ON, M5S 3H6, Canada \\ ${ }^{2}$ Department of Physics and Atmospheric Science, Dalhousie University, Halifax, NS, B3H 4R2, Canada \\ ${ }^{3}$ Département de Biologie (Québec-Océan), Université Laval, Québec City, QC, G1V 0A6, Canada \\ ${ }^{4}$ Institut des sciences de la mer de Rimouski, Université du Québec à Rimouski, Rimouski, QC, G5L 3A1, Canada \\ ${ }^{5}$ Department of Chemistry, University of British Columbia, Vancouver, BC, V6T 1Z1, Canada \\ ${ }^{6}$ Johannes Gutenberg University of Mainz, Institute of Atmospheric Physics, 55099 Mainz, Germany \\ ${ }^{7}$ Center for Earth Observation Science, University of Manitoba, Winnipeg, MB, R3T 2N2, Canada
}

Correspondence to: Douglas B. Collins (douglas.collins@utoronto.ca)

Received: 3 May 2017 - Discussion started: 6 June 2017

Revised: 13 September 2017 - Accepted: 29 September 2017 - Published: 7 November 2017

\begin{abstract}
The source strength and capability of aerosol particles in the Arctic to act as cloud condensation nuclei have important implications for understanding the indirect aerosolcloud effect within the polar climate system. It has been shown in several Arctic regions that ultrafine particle (UFP) formation and growth is a key contributor to aerosol number concentrations during the summer. This study uses aerosol number size distribution measurements from shipboard expeditions aboard the research icebreaker CCGS Amundsen in the summers of 2014 and 2016 throughout the Canadian Arctic to gain a deeper understanding of the drivers of UFP formation and growth within this marine boundary layer. UFP number concentrations (diameter $>4 \mathrm{~nm}$ ) in the range of $10^{1}-10^{4} \mathrm{~cm}^{-3}$ were observed during the two seasons, with concentrations greater than $10^{3} \mathrm{~cm}^{-3}$ occurring more frequently in 2016. Higher concentrations in 2016 were associated with UFP formation and growth, with events occurring on $41 \%$ of days, while events were only observed on $6 \%$ of days in 2014. Assessment of relevant parameters for aerosol nucleation showed that the median condensation sink in this region was approximately $1.2 \mathrm{~h}^{-1}$ in 2016 and $2.2 \mathrm{~h}^{-1}$ in 2014, which lie at the lower end of ranges observed at even the most remote stations reported in the literature. Apparent growth rates of all observed events in both expedi-
\end{abstract}

tions averaged $4.3 \pm 4.1 \mathrm{~nm} \mathrm{~h}^{-1}$, in general agreement with other recent studies at similar latitudes. Higher solar radiation, lower cloud fractions, and lower sea ice concentrations combined with differences in the developmental stage and activity of marine microbial communities within the Canadian Arctic were documented and help explain differences between the aerosol measurements made during the 2014 and 2016 expeditions. These findings help to motivate further studies of biosphere-atmosphere interactions within the Arctic marine environment to explain the production of UFP and their growth to sizes relevant for cloud droplet activation.

\section{Introduction}

Polar regions have been experiencing more rapid climate changes than the mid-latitudes (AMAP, 2012; Vaughan et al., 2013), prompting enhanced research activities in both the Arctic and Antarctic. Arctic sea ice extent, for instance, has been decreasing throughout the modern period of satellite measurements (Simmonds, 2015; Stroeve et al., 2012). The expansion of open water in the Arctic could lead to an increase in anthropogenic pollution sources due to increased access to shipping routes (Law and Stohl, 2007) along 
with possible enhancements in natural ocean-atmosphere exchange processes (Browse et al., 2014; Levasseur, 2013), some of which could influence concentrations of precursors for aerosol formation (Becagli et al., 2016; Rempillo et al., 2011; Sharma et al., 2012; Shaw et al., 2010). In general, changes in natural aerosol particle production and subsequent atmospheric processes contribute importantly to uncertainty in aerosol-cloud-climate interactions (Carslaw et al., 2013; Tsigaridis et al., 2013).

With important effects on cloud formation through their role as cloud condensation nuclei $(\mathrm{CCN})$, understanding the sources, sinks, and physicochemical properties of atmospheric aerosol particles is important for predicting cloud microphysics and aerosol indirect effects on climate (Carslaw et al., 2013; Ramanathan et al., 2001). Low-level clouds in the Arctic have a substantial impact on both the shortwave and longwave radiation balance depending on the season, with cooling effects on climate dominating in the summer (Intrieri et al., 2002b; Lubin and Vogelmann, 2010; Walsh and Chapman, 1998). In general, the extent of Arctic low-level liquid clouds reaches a maximum in the warm season, especially over the oceans (Cesana et al., 2012; Intrieri et al., 2002a), where the sensitivity of radiative forcing due to the aerosol indirect effect is strongest due to large differences in surface and cloud albedo.

During Arctic summer, the relatively high cloud fraction and greater degree of in-cloud and below-cloud aerosol scavenging play an important role in reducing ambient aerosol concentrations compared with winter and spring (Browse et al., 2012; Croft et al., 2016b), in addition to evidence for weaker long-range transport of pollutants from mid-latitudes in summer (Stohl, 2006). Typically, CCN-active aerosol particles with critical supersaturations relevant to marine stratiform liquid cloud formation are thought to have diameters $\left(d_{\mathrm{p}}\right)$ similar to or greater than $100 \mathrm{~nm}$ (depending on composition), corresponding roughly to so-called "accumulation mode" aerosol (Hegg et al., 2012). In environments with low $\mathrm{CCN}$ concentrations, the sensitivity of cloud droplet number concentrations to changes in $\mathrm{CCN}$ are typically stronger than cases with larger CCN concentrations (Ramanathan et al., 2001). Seasonal trends in aerosol size distribution measurements have consistently shown that sub- $100 \mathrm{~nm}$ particles are more abundant than accumulation mode particles throughout the Arctic during summer in the boundary layer (e.g., Asmi et al., 2016; Croft et al., 2016b; Heintzenberg et al., 2015; Nguyen et al., 2016; Tunved et al., 2013); such small particles would require greater water vapour supersaturations to nucleate cloud droplets than accumulation mode particles. The seasonal shift in the size distribution toward smaller particles in summer is therefore consistent with the suggestion that cloud microphysical changes can be somewhat insensitive to ground-level aerosol concentrations in the Arctic summer (Garrett et al., 2004).

New results challenge that view. In particular, a recent chemical transport model study, validated by aircraft mea- surements in the Canadian Arctic, suggests a relatively strong sensitivity between cloud droplet number concentration and aerosol concentration in the summertime Arctic (Moore et al., 2013). In situ measurements of liquid clouds in the Canadian Arctic performed in summer 2014, coincident with some of the data presented within the present study, indicate that accumulation mode aerosol particles were often acting as the principal cloud droplet nuclei in lower-level clouds (cloud base $<200 \mathrm{~m}$ ). However, in higher-altitude clouds (cloud base $>200 \mathrm{~m}$ ), the minimum diameter of a $\mathrm{CCN}$-active particle was substantially less than $100 \mathrm{~nm}$, suggesting that water vapour supersaturations in clouds with higher base heights were greater than expected (Leaitch et al., 2016); Arctic clouds could respond to changes in sub$100 \mathrm{~nm}$ aerosol concentrations as long as the concentrations of particles larger than $100 \mathrm{~nm}$ were sufficiently low. Since the concentration of sub- $100 \mathrm{~nm}$ aerosol particles in summer is typically greater than the accumulation mode number concentration (e.g., Asmi et al., 2016; Heintzenberg et al., 2015; Leaitch et al., 2013; Nguyen et al., 2016; Tunved et al., 2013), their production is of great importance to cloud properties in Arctic summer provided that water vapour supersaturations can exceed critical supersaturations for such small particles, as shown by Leaitch et al. (2016). The nature of the sub$100 \mathrm{~nm}$ aerosol source, its strength or production flux, and the physicochemical properties of the particles in question are all key parameters to constrain.

The relatively high concentrations of sub- $100 \mathrm{~nm}$ particles in the Arctic during summer have been mostly associated with aerosol nucleation (Asmi et al., 2016; Chang et al., 2011; Giamarelou et al., 2016; Heintzenberg et al., 2015; Karl et al., 2012; Kolesar et al., 2017; Leaitch et al., 2013; Shaw, 1989; Ström et al., 2009; Tunved et al., 2013; Wiedensohler et al., 1996), although contributions from primary marine aerosol (Leck and Bigg, 2005) and the evaporation of fogs have been suggested as well (Leck and Bigg, 2010). Ultrafine particles (UFP), defined in this study as aerosol particles with $d_{\mathrm{p}}=4-20 \mathrm{~nm}$, have a vertical profile maximum in the Arctic boundary layer both in the Canadian Archipelago and in the vicinity of Svalbard (Burkart et al., 2017; Engvall et al., 2008b), suggesting a source of UFP at or near the Earth's surface. While the source regions and precursor components are still a topic of active research, studies have shown that ammonia $\left(\mathrm{NH}_{3}\right)$ and dimethyl sulfide (DMS) are associated with the formation and growth of UFP in the Arctic (Chang et al., 2011; Croft et al., 2016a; Ferek et al., 1995; Ghahremaninezhad et al., 2016; Giamarelou et al., 2016; Heintzenberg and Leck, 1994; Leaitch et al., 2013; Leck and Persson, 1996), with likely contributions from organic material during particle growth (Willis et al., 2016). Biogenic iodine compounds have also been implicated in UFP formation in temperate coastal areas (Mäkelä et al., 2002; O'Dowd et al., 2002) and in polar regions (Allan et al., 2015; Sipilä et al., 2016) due to emissions from marine macroalgae within intertidal zones. UFP formation has also been observed within 
the Arctic marginal ice zone (e.g., Karl et al., 2012) and emissions of precursor gases have been associated with biological communities on or near sea ice margins (Dall'Osto et al., 2017a; Levasseur, 2013). Overall, most studies have suggested that marine, coastal, and/or marginal ice sources contribute to the formation and growth of UFP in the Arctic (Burkart et al., 2017; Chang et al., 2011; Croft et al., 2016a; Heintzenberg et al., 2015; Karl et al., 2012; Sharma et al., 2012; Willis et al., 2016). A recent study in Alaska, however, has shown that UFP formation and growth can also be strongly influenced by anthropogenic emissions associated with oil production activities (Kolesar et al., 2017), at least for regions proximal to such activities.

This study uses aerosol measurements from two Arctic summertime campaigns aboard the icebreaker CCGS Amundsen in 2014 and 2016 to investigate the frequency of, and factors contributing to, UFP formation and particle growth toward CCN-relevant sizes within the marine boundary layer. Detailed size distribution analyses of UFP formation and growth events in Arctic locations have only recently been published (Asmi et al., 2016; Kolesar et al., 2017; Nguyen et al., 2016), and the present study is the first to present such an analysis strictly within the Arctic marine environment. The study is unique in its wide and consistent spatial coverage across two expeditions, the similar seasonal timing of the expeditions, and the large number of co-sampled atmospheric and oceanic parameters, permitting a wide range of environmental conditions to be considered. Specifically, these data are distinct from the more numerous Arctic UFP data sets that have been gathered at long-term monitoring stations located on land.

The general characteristics of the atmospheric aerosol measured during each campaign will be described in detail and comparisons between expeditions will be made in light of their environmental similarities and differences. Further, in order to constrain the range of conditions that may limit UFP formation and growth in the Arctic marine environment, meteorological and oceanic conditions were investigated throughout each of the expeditions. The goal of this study is to define the frequency and characteristics of UFP formation and growth within the remote Canadian Arctic, to characterize the environmental factors that are associated with UFP formation in the Arctic marine boundary layer, and to provide broad motivation for a more comprehensive understanding of precursors to aerosol formation and growth in the marine/coastal environment.

\section{Measurement methods}

\subsection{Atmospheric aerosol measurements}

Measurements of ambient atmospheric aerosol were conducted between 15 July and 12 August 2014 and between 20 July and 23 August 2016 aboard the research icebreaker

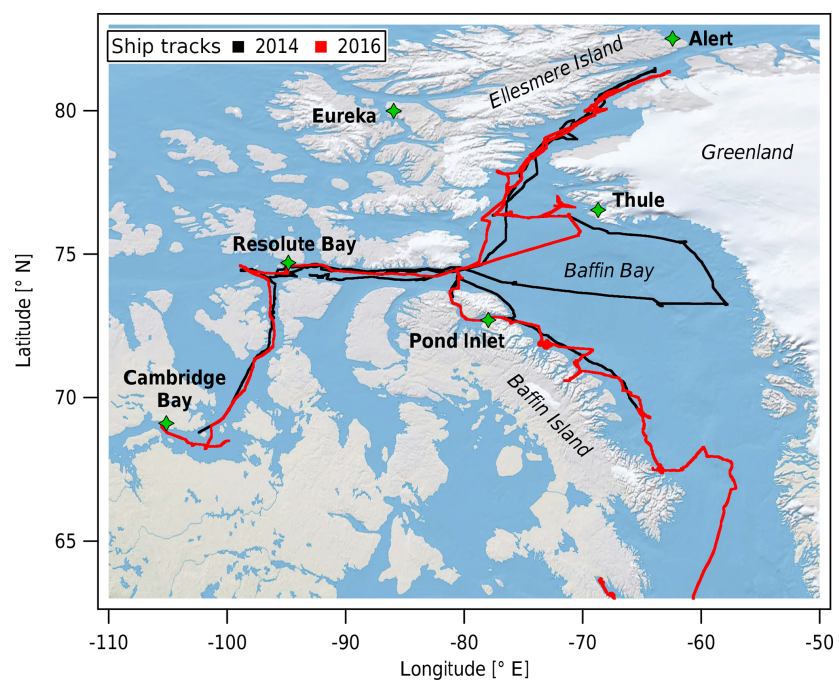

Figure 1. Cruise track of CCGS Amundsen comprising the NETCARE 2014 and 2016 campaigns. In both expeditions, the ship progressed generally from southern Baffin Bay, north toward Alert, and then south toward Resolute Bay and Cambridge Bay, traversing the Northwest Passage.

CCGS Amundsen, operating within the Canadian Arctic as part of a multi-year research project, NETCARE (Network on Climate and Aerosols: Addressing Key Uncertainties in Remote Canadian Environments). The cruise track for each of the two field campaigns is provided in Fig. 1.

Ambient concentrations of aerosol with $d_{\mathrm{p}}>4 \mathrm{~nm}$ were measured using an ultrafine condensation particle counter (UCPC; model 3776, TSI, Inc.), operating with an inlet flow rate of $1.5 \mathrm{~L} \mathrm{~min}^{-1}$. While the nominal lower size limit for detectable particles for this instrument was specified by the manufacturer at $2.5 \mathrm{~nm}$, diffusional losses of particles in the tubing (stainless steel, $4.57 \mathrm{~mm}$ inner diameter) increased the practical lower size limit to approximately $4 \mathrm{~nm}$. Concentrations were sampled at $1 \mathrm{~Hz}$ and were subsequently averaged to time bins of coarser resolution for calculating various size-resolved aerosol metrics in conjunction with other data products. Number size distributions of particles between 10 and $430 \mathrm{~nm}$ were measured using a scanning mobility particle sizer (SMPS; model 3080/3787, TSI, Inc.) operating with a sample flow rate of $0.6 \mathrm{~L} \mathrm{~min}^{-1}$ and a sheath air flow rate of $6.0 \mathrm{~L} \mathrm{~min}^{-1}$. SMPS and UCPC sampled from the starboard side of the ship's foredeck, approximately $5 \mathrm{~m}$ aft of the bow and approximately $7 \mathrm{~m}$ above the sea surface. Number size distributions of particles with diameter between 0.54 and $20 \mu \mathrm{m}$ were measured with an aerodynamic particle sizer (APS; model 3321, TSI, Inc.) from atop the ship's bridge using a louvered inlet designed for total suspended particle transmission and a straight vertical stainless steel tube ( $16.56 \mathrm{~mm}$ inner diameter) coupled directly to the inlet of the APS (total flow rate $5 \mathrm{~L} \mathrm{~min}^{-1}$ ). 
The influence of ship exhaust was excluded from the 2016 data by applying a wind direction filter to the data in postprocessing with an acceptance angle of $60^{\circ}$ to port and $90^{\circ}$ to starboard of the ship's heading. Extension of the acceptance angle to $90^{\circ}$ on the starboard side is related to the position of the sampling inlet near the starboard edge of the ship on the foredeck; winds arriving at the sampling inlet directly perpendicular to the ship's heading from the starboard side were free from ship exhaust contamination. Within the 2014 data set, high frequency fluctuations in aerosol concentration, caused by intermittently sampling ship exhaust, remained in the data record after filtering with the aforementioned wind direction criteria. The influence of ship exhaust was excluded from the 2014 data by first discarding all data points with SMPS concentrations $>5000 \mathrm{~cm}^{-3}$ and UCPC concentrations $>10000 \mathrm{~cm}^{-3}$. Further, the SMPS data were filtered for time periods where particle concentrations increased by more than $200 \%$ of the median of the preceding 10 consecutive valid measurements, given that the elevated concentration only persisted for less than three data points. Periods in which SMPS total concentrations varied continuously by more than $200 \%$ were also excluded, as they indicated sustained sampling of transient ship exhaust plumes. The difference in data filtering method between the two years arises from different relative wind direction frequency distributions and the rate at which the wind direction changed relative to the ship's compass heading. Using only the wind direction filter for the 2014 data would have preserved its main features but also would have included some undesirable ship exhaust signal.

Total aerosol concentration and number size distribution data were used to calculate various metrics to describe the aerosol characteristics succinctly. The number concentration of particles with $d_{\mathrm{p}}=4-20 \mathrm{~nm}\left(N_{4-20}\right)$ has been used previously as a metric for UFP (e.g., Burkart et al., 2017; Leaitch et al., 2013) and was obtained using Eq. (1):

$N_{4-20}=N_{\mathrm{UCPC}}-\int_{20}^{430} N\left(d_{\mathrm{p}}\right) \mathrm{d} d_{\mathrm{p}}$,

where $N_{\mathrm{UCPC}}$ is the total concentration of particles measured by the UCPC, $N\left(d_{\mathrm{p}}\right)$ is the number size distribution obtained from the SMPS, and the limits of the integral are in units of nanometres. In addition to $N_{4-20}$, the quantity $N_{4-10}$ was calculated and represents the difference between the total concentration measured by the UCPC (lower limit $d_{\mathrm{p}}=4 \mathrm{~nm}$ ) and the SMPS (lower limit $d_{\mathrm{p}}=10 \mathrm{~nm}$ ). The aerosol condensation sink (CS) was calculated using both SMPS and APS data according to Eqs. (2) and (3) (Dal Maso et al., 2002):

$\mathrm{CS}=2 \pi D \sum_{i} \beta_{i} d_{\mathrm{p} i} N_{i}$,

where $i$ represents a size bin of particles with diameter $d_{\mathrm{p} i}$ and number concentration $N_{i}$. D is the diffusion coefficient given a value of $7 \times 10^{-6} \mathrm{~m}^{2} \mathrm{~s}^{-1}$, corresponding to an oxidized organic molecule (Tang et al., 2015). The FuchsSutugin transition regime correction factor $\beta_{i}$ was computed in each size bin using Eq. (3):

$$
\beta_{i}=\frac{1+K n}{1+\left(\frac{4}{3 \alpha}+0.337\right) K n+\frac{4}{3 \alpha} K n^{2}},
$$

where $\alpha$ is the dimensionless sticking coefficient $(\alpha=1), K n$ is the (dimensionless) Knudsen number, $2 \lambda / d_{\mathrm{p}}$, and $\lambda$ is the mean free path of vapour molecules $(\lambda=65 \mathrm{~nm})$.

\subsection{Atmospheric state measurements and air mass history modelling}

Meteorological state variables (e.g., wind direction, wind speed, relative humidity ( $\mathrm{RH}$ ), and temperature) were measured from a tower on the ship's foredeck. RH and air temperature were measured using a shielded probe (Vaisala ${ }^{\mathrm{TM}}$ HMP45C212 in 2014 and HMP155A in 2016) at approximately $14.5 \mathrm{~m}$ and $16.3 \mathrm{~m}$ above sea level during, respectively, the 2014 and 2016 cruises. Wind direction and speed were measured using a wind monitor (RM Young ${ }^{\mathrm{TM}} 05103$ 10), positioned at $16.2 \mathrm{~m}$ and $17.6 \mathrm{~m}$ above sea level in 2014 and 2016. Sensors were scanned every $2 \mathrm{~s}$ and saved as 2 min averages to a micrologger (Campbell Scientific ${ }^{\mathrm{TM}}$, model CR3000). Platform relative wind was post-processed to true wind following Smith et al. (1999). Navigation data (ship position, speed over ground, course over ground and heading) necessary for the conversion were available from the ship's position and orientation system (Applanix POS MV ${ }^{\mathrm{TM}} \mathrm{V} 4$ ). Periods when the tower sensors were serviced or when the platform relative wind were beyond $\pm 90^{\circ}$ from the ship's bow were screened from the data set. Downwelling shortwave solar radiation was measured using a pyranometer (Eppley, model PSP) secured to a purpose built platform atop the ship's bridge. The sensor was scanned every second and stored as 2 min averages on a micrologger (Campbell Scientific $^{\mathrm{TM}}$, model CR1000).

Air mass histories were computed using the Flexible Particle Dispersion (FLEXPART) model driven by meteorological analysis data from the European Centre for MediumRange Weather Forecast (ECMWF). The analysis data are used with a horizontal grid spacing of $0.25^{\circ}$ in longitude and latitude with 137 hybrid-pressure levels in the vertical. Tracers are inert, non-interacting particles that are released from the ship's position every $6 \mathrm{~h}$. Tracers were continuously released for $1 \mathrm{~h}$ between 10 and $20 \mathrm{~m}$ above sea level. FLEXPART was run in backward mode and model output is given as the spatially resolved potential emission sensitivity (PES) (which is proportional to the residence time of a tracer in a given region) of the tracer particles over a particular location, available every 3 . PES represents the amount of time that an air mass may be influenced by emissions from a given location in space and time. For analysis in this study, PES has been vertically integrated from the surface up to both $200 \mathrm{~m}$ and $10 \mathrm{~km}$ above mean sea level and time-integrated for 5 days $(120 \mathrm{~h})$ leading up to the release time. Maps were generated using the Basemap toolkit for Python (v3.6). 


\subsection{Satellite observations}

Satellite retrievals were used to estimate cloud cover and sea ice concentration in the study region. Cloud cover was estimated using the monthly Level 3 Aqua MODIS mean liquid cloud fraction product (http://modis-atmos.gsfc.nasa.gov/ MOD08_M3/). Data were obtained for all latitudes from 30 to $90^{\circ} \mathrm{N}$ at $1^{\circ}$ spatial resolution for the months August 2014 and August 2016 through the United States National Aeronautics and Space Administration (NASA) Goddard Space Flight Center (GSFC) Giovanni interface (https://giovanni. sci.gsfc.nasa.gov/giovanni/). Average values for cloud fraction were calculated within a box bounded by the limits $68-$ $82^{\circ} \mathrm{N}$ and $55-110^{\circ} \mathrm{W}$, inclusive. Sea ice was assessed from the National Snow and Ice Data Center (NSIDC) Defense Meteorological Satellite Program Special Sensor Microwave Imager Sounder (SSMIS) Daily Polar Gridded Sea Ice Concentrations (http://nsidc.org/data/nsidc-0081) (Maslanik and Stroeve, 1999). Data were retrieved for 15 July-31 August in both 2014 and 2016. Both cloud fraction and sea ice concentration data were visualized using the NASA Panoply Data Viewer (https://www.giss.nasa.gov/tools/panoply/).

\subsection{Oceanic measurements}

Sea surface temperature was measured through the ship's inboard ShipTrack water system using a Seabird/Seapoint measurement system. Samples for the concentration of DMS in seawater $\left(\mathrm{DMS}_{\mathrm{sw}}\right)$ were collected from the sea surface via Niskin-type bottles (OceanTest Equipment) in 2014 $($ depth $=0-0.5 \mathrm{~m})$ and using the underway seawater sampler aboard the CCGS Amundsen in 2016 (depth = 4 m), allowing for greater spatial resolution. In 2014, discrete samples of $\mathrm{DMS}_{\mathrm{sw}}$ were quantified aboard the ship within $2 \mathrm{~h}$ of collection by gas chromatography (GC; Varian 3800) following purging with helium (flow rate of $50 \mathrm{~mL} \mathrm{~min}^{-1}$ ) and cryotrapping in liquid nitrogen as described by $\mathrm{Li}$ zotte et al. (2012). In 2016, $\mathrm{DMS}_{\mathrm{sw}}$ was quantified by gas chromatography-mass spectrometry (GC/MS; Agilent 7890A/5975C) coupled to a permeable gas membrane module $\left(\right.$ PermSelect ${ }^{\circledR}$ ) with $7500 \mathrm{~cm}^{2}$ of exchange surface and a multimodal cryogenic trap inlet. Automated measurements of $\mathrm{DMS}_{\mathrm{sw}}$ were taken and logged every $10 \mathrm{~min}$ and linked with the ship's global positioning system through customdesigned LabView software (StudioBods, Inc.). A constant flow $\left(0.2 \mathrm{~mL} \mathrm{~min}^{-1}\right)$ of a standard solution of $\mathrm{d}_{3}$-DMS and $\mathrm{d}_{6}$-DMS in the seawater line upstream (constant flow of $100 \mathrm{~mL} \mathrm{~min}^{-1}$ ) of the permeable membrane allowed for continuous dual internal isotopic calibration.

Samples for dissolved organic carbon (DOC), chlorophyll $a$ (chl $a$ ), and primary production (PP) were collected via Niskin-type bottle or a bucket at the sea surface (depth $<4 \mathrm{~m})$. DOC was determined using a hightemperature combustion Shimadzu TOC-V $\mathrm{V}_{\mathrm{CPN}}$ Total Organic Carbon Analyzer, as described in detail by Mungall et al. (2017). Chl $a$ concentrations an index of phytoplankton biomass, was measured using a 10-AU Turner Designs fluorometer following the acidification method of Parsons et al. (1984). PP was estimated using the ${ }^{14} \mathrm{C}$-assimilation method during $24 \mathrm{~h}$ simulated in situ deck incubations (Ardyna et al., 2011; Knap et al., 1996). Chl $a$ and PP were both measured on particles retained on Whatman GF/F filters (nominal pore size of $0.7 \mu \mathrm{m}$ ) and $5 \mu \mathrm{m}$ Nuclepore polycarbonate membrane filters.

Vertically resolved seawater samples for nitrate $\left(\mathrm{NO}_{3}^{-}\right)$determinations were collected with Niskin bottles attached to a CTD rosette water sampler. The concentrations of $\mathrm{NO}_{2}^{-}$(nitrite) and $\mathrm{NO}_{3}^{-}+\mathrm{NO}_{2}^{-}$were measured on fresh samples with a Bran+Luebbe Auto-Analyzer 3 using adaptations of the colorimetric methods of Grasshoff et al. (2009), with an analytical detection limit of $0.03 \mu \mathrm{M}$. Nitrate was obtained by difference of $\mathrm{NO}_{3}^{-}+\mathrm{NO}_{2}^{-}$and $\mathrm{NO}_{2}^{-}$measurements.

Expedition-wide analysis of environmental parameters measured aboard CCGS Amundsen was performed by calculating the number of observations that fell within prescribed bins of each quantity (e.g., $\mathrm{DMS}_{\mathrm{sw}}$, solar radiation, $\mathrm{RH}$ ). Each frequency distribution was then normalized such that the sum of the frequencies across all bins was unity, similar to a probability distribution. For satellite products, averages and average differences in sea ice and cloud fraction were obtained by vectorizing the spatially resolved matrix of data before computing the mean. Grid points with missing data were disregarded from statistical analysis. This data analysis approach precluded spatial patterns from influencing statistics, so that all points within the study region were treated with equal weight. All calculations were performed using standard MATLAB ${ }^{\circledR}$ functionality (version R2016b; The MathWorks, Inc.).

\section{Results and discussion}

Measurements of aerosol total number concentration and size-resolved number concentration from 32 days in 2014 and 34 days in 2016 were analysed to investigate factors contributing to formation and growth of UFP. In the following sections, general observations of ultrafine particles in the Canadian Arctic are reported and discussed in the context of surrounding environmental conditions.

\subsection{Ultrafine particle concentrations}

Summertime UFP concentrations $\left(N_{4-20}\right)$ in the Canadian Arctic marine environment had a range of about 3 orders of magnitude (approx. 10 $10^{1}-10^{4} \mathrm{~cm}^{-3}$ ) during 2014 and 2016 observation periods. Histograms of $N_{4-20}$ measured aboard the CCGS Amundsen are given in Fig. 2. Most commonly, $N_{4-20}$ was between 50 and $100 \mathrm{~cm}^{-3}$ for both 2014 and 2016, but differences are evident when examining the frequency at which higher concentrations were observed. Sum- 


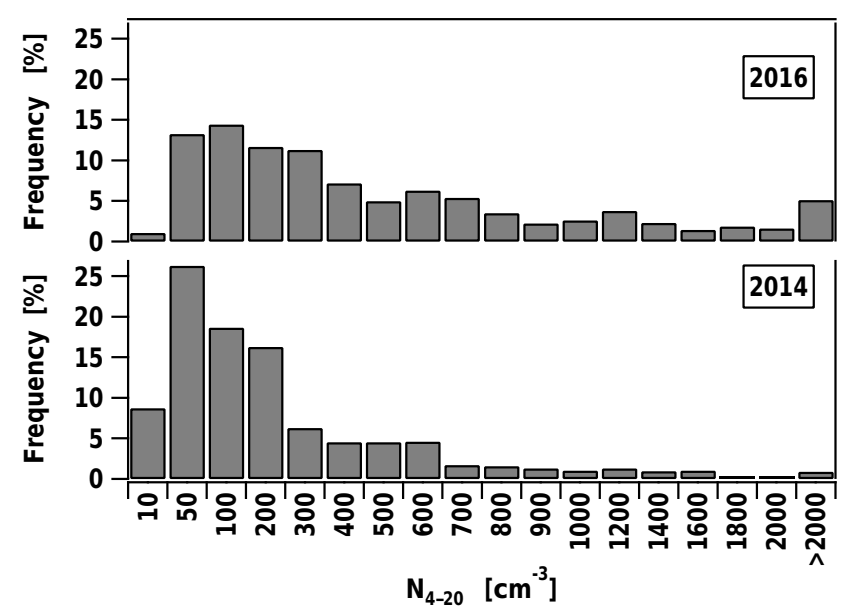

Figure 2. Frequency distributions of ultrafine particle concentrations $\left(N_{4-20}\right)$ based on $5 \mathrm{~min}$ averaged measurements for the 2016 (top) and 2014 (bottom) expeditions. Bins are labelled with the upper limit, except for the rightmost bin, which is labelled with its lower limit $\left(>2000 \mathrm{~cm}^{-3}\right)$.

mer 2016 exhibited a greater frequency of observations with $N_{4-20}>1000 \mathrm{~cm}^{-3}$, with $5.1 \%$ of the $5 \mathrm{~min}$ average measurements of $N_{4-20}$ in excess of $2000 \mathrm{~cm}^{-3}$ ( $<1 \%$ of observations exceeded $2000 \mathrm{~cm}^{-3}$ during the 2014 cruise). The absolute maximum 5 min average $N_{4-20}$ concentration observed in 2016 was $9350 \mathrm{~cm}^{-3}$, whereas the maximum $5 \mathrm{~min}$ average concentration in 2014 was $5521 \mathrm{~cm}^{-3}$. It should be noted that maximum $1 \mathrm{~s}$ concentrations observed by the UCPC in 2016 were in excess of $10^{4} \mathrm{~cm}^{-3}$ and were observed during UFP formation events, but they were shortlived in the time series (smooth features lasting 5-15 min) due to various factors, including ship movement.

Elevated $N_{4-20}$ concentrations were observed in similar locations during 2014 and 2016. In 2014, $N_{4-20}$ was in excess of $1000 \mathrm{~cm}^{-3}$ on fewer isolated occasions than in 2016 (Figs. 2 and 3). Instances of elevated $N_{4-20}$ in 2014 were located along the northeast coast of Baffin Island, near the eastern extent of Lancaster Sound (near Pond Inlet and Bylot Island), in Upper Baffin Bay near the coast of Greenland, and within Nares Strait (between Ellesmere Island and Greenland). On two of these occasions, size distribution measurements indicated that UFP formation and/or growth was occurring, as the temporal profile of the size distributions resembled that of typical aerosol nucleation events observed in more heavily studied continental regions (Kulmala et al., 2014). Occasions in which $N_{4-20}>1000 \mathrm{~cm}^{-3}$ in 2014 were localized to a few regions: the northeast coast of Baffin Island, around Bylot Island (near Pond Inlet), in Upper Baffin Bay near the coast of Greenland, within the Nares Strait, and in the Franklin Strait/Queen Maud Gulf region within the Northwest Passage (south of Resolute Bay). With perhaps the exception of the Franklin Strait/Queen Maud Gulf region, for each of the locations in which elevated $N_{4-20}$ was observed in 2014, generally similar trends in concentration were observed in 2016. In most cases, high $N_{4-20}$ concentrations were associated with aerosol nucleation and/or particle growth, as discussed in detail below. The significant degree of spatial consistency in $N_{4-20}$ between 2014 and 2016 supports the notion that the production process for UFP may be consistent and/or geographically localized within the Canadian Arctic.

\subsection{Ultrafine particle formation events}

\subsubsection{Temporal characteristics and general description}

Associated with the higher frequency of elevated $N_{4-20}$ concentrations in 2016 compared with 2014, the number of instances in which UFP were observed to form and grow in diameter was also greater in 2016. A UFP formation event is defined here as a temporally contiguous period (scale of hours) in which $N_{4-20}$ was elevated, SMPS measurements indicate that particles were observed in the smallest size bins, and the slope in modal size of particles over time was positive. A particle growth event is defined as a temporally contiguous period (scale of hours-days) in which SMPS measurements indicate that particles were steadily increasing in diameter (but not necessarily starting from the smallest measurable sizes in the SMPS); growth events may include one dominant population (mode) of particles or multiple distinct modes growing simultaneously. Regions in which UFP formation and/or growth events were observed are indicated by black boxes in Fig. 3. While there were many more instances of UFP formation and growth events in 2016, the two locations in which UFP formation was observed in 2014 were roughly co-located with events observed in 2016.

Two example time periods from the 2016 campaign are shown in Fig. 4. It should be noted that in both example cases, the ship was moving ahead at approximately $6 \mathrm{~m} \mathrm{~s}^{-1}$, which could affect apparent particle growth rates and/or the appearance/disappearance of events. Both events show noticeable increases in $N_{4-10}$ in the beginning with its fractional contribution to $N_{\text {total }}$ decreasing with time. In addition, substantial concentrations of particles in the smallest bins of the SMPS were observed at the beginning of the event, providing strong evidence that the events observed can be characterized as aerosol nucleation (Kulmala et al., 2014; Zhang et al., 2012).

In Fig. 4a, a "gap" in the event, where particle concentrations drop abruptly to less than $1000 \mathrm{~cm}^{-3}$, was observed during which the ship moved through a bank of low fog. Particle concentrations likely were reduced due to fog scavenging processes (i.e., nucleation scavenging, impaction scavenging) and/or local depletion of aerosol growth precursor gases by uptake to fog droplets (Pruppacher and Klett, 2010). After the ship travelled through the fog (approx. $11 \mathrm{~km}$ ), characteristics of the event resumed in a similarly abrupt way, indicating that the fog patch was contained within the 


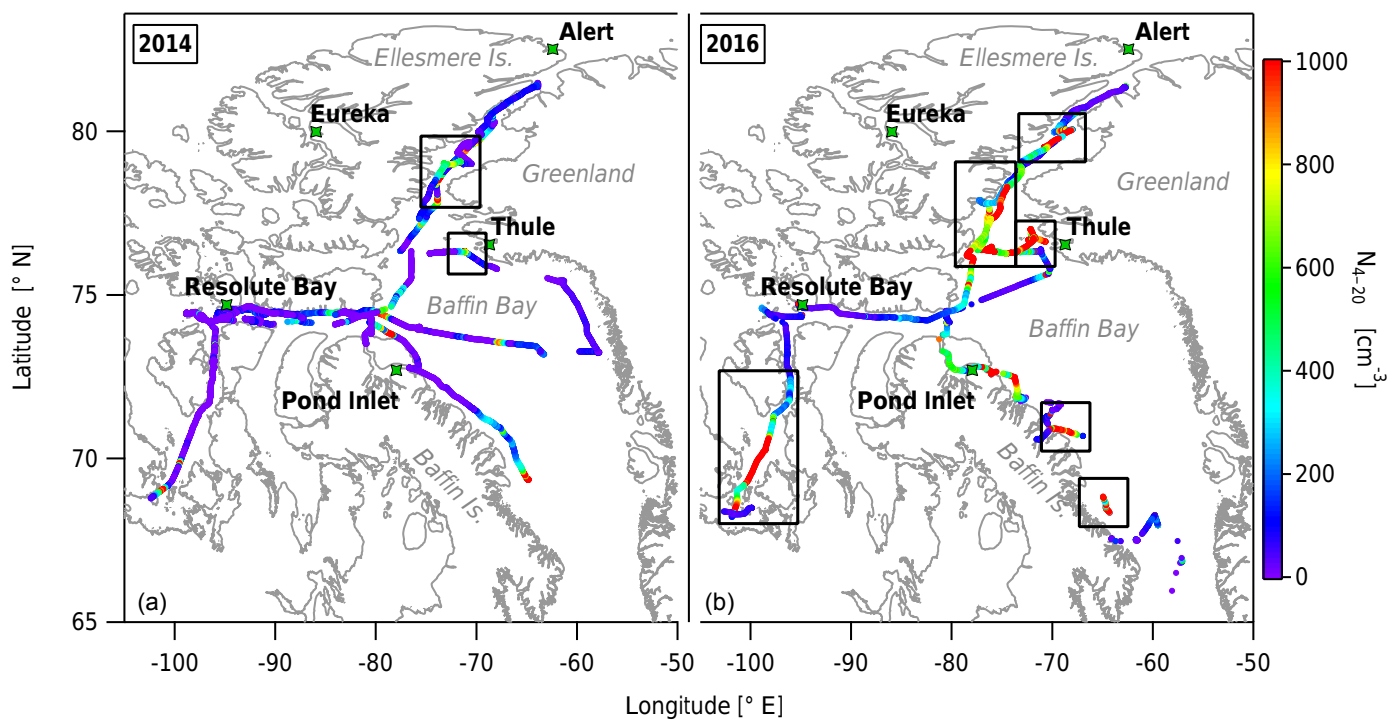

Figure 3. Spatially resolved measurements of $N_{4-20}$ for the NETCARE 2014 (a) and 2016 (b) campaigns. Boxes denote locations where UFP formation and growth were observed.
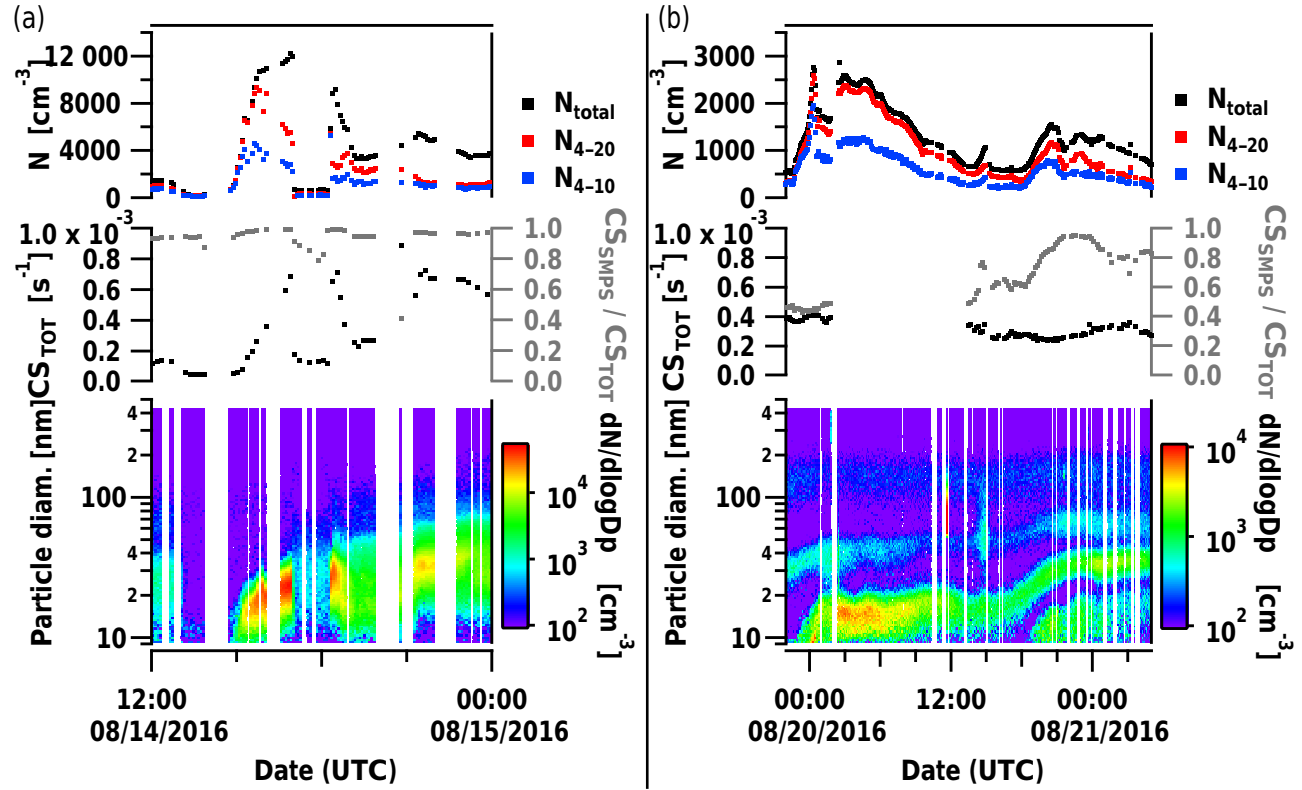

Figure 4. Examples of a new particle formation and growth events observed during the NETCARE 2016 campaign. (a) An example observed in the Nares Strait, during which the ship moved through a shallow fog, resulting in a period of low particle concentrations amidst a larger-scale nucleation event. (b) The Peele Sound/Queen Maud Gulf region (south of Resolute Bay) nucleation was observed, and a subsequent nucleation event caused simultaneous growth of particles formed previously. Indeed, there is evidence for three modes growing simultaneously near the end of the event period. The top panels show 1 min average particle concentrations in three size classes, $N_{\text {total }}$ $\left(d_{\mathrm{p}}>4 \mathrm{~nm}\right)$, along with $N_{4-20}$ and $N_{4-10}$. Middle panels show the condensation sink $\left(\mathrm{CS}_{\mathrm{TOT}}\right)$ and the fraction of CS contributed by particles with $d_{\mathrm{p}}=10-500 \mathrm{~nm}\left(\mathrm{CS}_{\mathrm{SMPS}} / \mathrm{CS}_{\mathrm{TOT}}\right)$. The bottom panels are time-resolved SMPS size distributions plotted with the concentrations on a logarithmic scale. Note the difference in concentration scale between panels (a) and (b) in both top and bottom panels.

broader spatial extent of the nucleation or growth event. Also, the peak concentration of particles was notable, as total particle concentrations in excess of $12000 \mathrm{~cm}^{-3}(1 \mathrm{~min}$ average; $d_{\mathrm{p}}>4 \mathrm{~nm}$ ) were observed during this event. This strong nu- cleation burst (along with other nucleation or growth events immediately following the event, shown in Fig. 6) was located in the Nares Strait, where an event was also observed in 2014 , suggesting the possibility of a substantial, consis- 

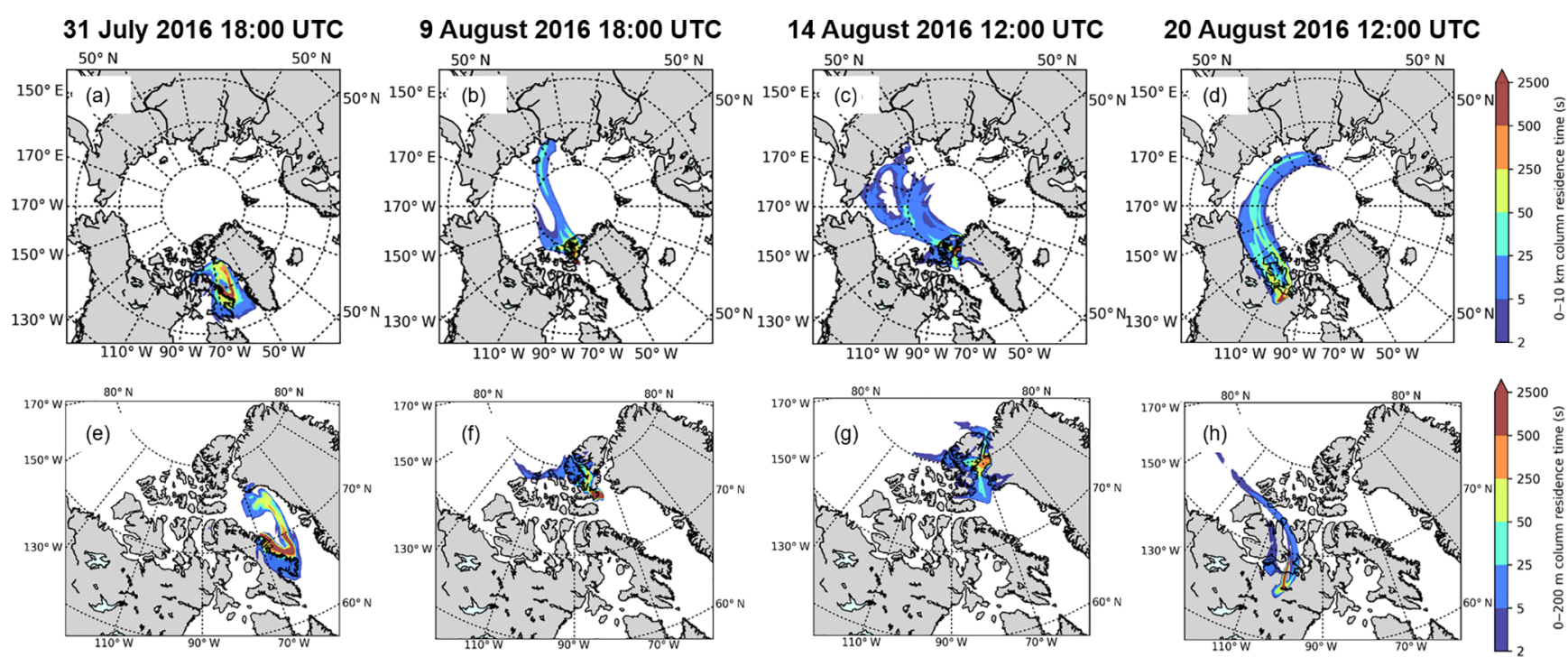

Figure 5. FLEXPART air mass histories extending backwards 5 days from the time noted at the top of each pair of plots. The top rows (a-d) represent time-integrated PES for a 0-10 km column, and the bottom rows (e-h) represent time-integrated PES for a 0-200 m column. Note the difference in projection and spatial scale in the panels (e-h) to emphasize the local detail of the 0-200 $\mathrm{m}$ PES. Each of the release times corresponds to the observation of a UFP formation and/or growth event aboard CCGS Amundsen. Tracer release locations were dictated by the ship's coordinates at the given release time. Details on the model are described in Sect. 2.2.

tent source of precursors in the region. Shipboard trace gas measurements in the same region of interest during the 2014 CCGS Amundsen expedition have shown elevated values of $\mathrm{NH}_{3(g)}$ (Wentworth et al., 2016), gas-phase DMS (Mungall et al., 2016), and evidence of an ocean source for oxygenated volatile organic compounds (Mungall et al., 2017) that may act as precursors for growth.

Previous detailed studies in the Arctic have shown that the occurrence of UFP formation and growth events was associated with biogenic sulfur compounds like DMS, which has a substantial oceanic source, and its lower vapour pressure oxidation products, methanesulfonic acid, and sulfuric acid $\left(\mathrm{H}_{2} \mathrm{SO}_{4}\right)$ (Chang et al., 2011; Ghahremaninezhad et al., 2016; Leaitch et al., 2013; Quinn et al., 2002; Rempillo et al., 2011). Other studies have shown that the duration of contact that the air mass had with open water along its backward trajectory was positively correlated with the occurrence of UFP formation (Asmi et al., 2016; Heintzenberg et al., 2015) and aerosol biogenic sulfur concentrations (Sharma et al., 2012). Recently, Kolesar et al. (2017) segregated air mass backward trajectories to show that the frequency of nucleation events observed at a station near the Beaufort Sea was greater for coastal-influenced air masses than those that were associated mainly with open water. Coastal areas can be associated with elevated emissions of various trace gases, including iodine species (Mäkelä et al., 2002), $\mathrm{NH}_{3}$ (Croft et al., 2016a; Wentworth et al., 2016), and/or reduced sulfur compounds (Bates and Cline, 1985; Leck and Rodhe, 1991; Turner et al., 1988). Coastal zones have also been shown to influence aerosol nucleation in locations outside the Arctic (O'Dowd et al., 2002; Weber et al., 1998). Air mass histories shown in Fig. 5 for four example events from 2016 indicate that within 5 days prior to each event, air was contained within the Arctic environment and largely over the ocean or sea ice, although coastal influence was notable as well, especially for the 31 July 2016 case (impacted by coastlines within Baffin Bay; Fig. 5a) and to some extent for the 20 August 2016 case (coastal influence along Northern Canada and Alaska; Fig. 5d). Despite $N_{4-20}>1000 \mathrm{~cm}^{-3}$ near Pond Inlet in 2016 (Fig. 3), neither UFP formation nor particle growth was observed in this region; the 5-day air mass history indicates that air sampled during this period was impacted strongly by Northern Canada and Alaska (Supplement Fig. S1). Overall, when considering locations within or near the Canadian Archipelago, coastal zones will likely also impact the air masses that have been "marine influenced". The largely marine and coastal influence for air masses with notable UFP formation and growth observed aboard CCGS Amundsen in 2014 and 2016 highlight the importance of oceanic sources for secondary aerosol precursors in the Arctic.

Another example period is shown in Fig. 4b. The beginning of this time period (until approximately 20 August 2016 15:00 UTC) was characterized by average $18.2 \mathrm{~m} \mathrm{~s}^{-1}$ apparent wind and an elevated sea state, leading to substantial local sea spray production; UFP formation was observed despite these conditions, as the condensation sink was approx. $4 \times 10^{-4} \mathrm{~s}^{-1}\left(1.4 \mathrm{~h}^{-1}\right)$, which is on the low end of ranges that were observed in the boreal forest, a North Atlantic coastal site, and on the northern coast of Alaska, where UFP formation and growth was also observed (Dal Maso et 
al., 2002; Kolesar et al., 2017; Westervelt et al., 2013) (see also Sect. 3.2.4). The following day, a subsequent new particle formation event was observed, causing the existing populations of particles to grow in parallel; the two modes of particles did not appear to be combined as a result of growth in the smaller mode. This type of successive particle growth was observed on multiple occasions in 2016 and may be an important mechanism for the growth of newly formed particles to sizes sufficient for $\mathrm{CCN}$ activity. In both cases, growth proceeded during daylight hours and ceased in periods of darkness (solar radiation $<50 \mathrm{~W} \mathrm{~m}^{-2}$ from 02:00 to 00:00 UTC on 15 August in Fig. 4a and from 01:30 UTC on 20 August to 12:30 UTC on 21 August in Fig. 4b); particle size distributions were temporally consistent through the night on each of the example occasions.

\subsubsection{Frequency of events}

The overall temporal profiles of SMPS size distributions (Fig. 6) show substantial differences between the overall concentrations, frequency of high particle concentration events, and the frequency with which particle growth was observed between the NETCARE 2014 and 2016 campaigns. In 2016, temporally contiguous periods can be seen in which particle concentrations were high (saturating the scale in Fig. 6) and tend toward growth of modal diameters over time. Growth from newly formed particles up to diameters approaching $100 \mathrm{~nm}$ can be seen occurring over the scale of days. It is important to note that the ship was moving during the vast majority of the campaign so the appearance and disappearance of events may be due to ship movement or changes in meteorological conditions. Overall, though, it is clear that conditions must have been more favourable for ultrafine particle formation and growth in 2016 than in 2014. Beyond the visible differences in size distributions shown in Fig. 6, UFP formation and growth were documented on 14 occasions in 2016 (41\% of observation days) and on 2 occasions in 2014 (6\% of observation days). Events tended to be observed on consecutive days, with defined gaps between groups of events; since the ship was moving most of the time, temporal grouping translated to regional grouping of nucleation and/or growth events.

\subsubsection{Particle growth rates}

Particle growth is an important factor driving the concentration of CCN in the Arctic summer (Willis et al., 2016). Growth of particles observed in this study was quantified by fitting the temporal trend in modal diameter to a line, where the slope is equal to the growth rate (Dal Maso et al., 2005). Since the measurements reported here were made on a moving measurement platform, growth rates should be seen as "apparent" growth rates $\left(\mathrm{GR}_{\mathrm{app}}\right)$, since ship movement and air mass advection could have influenced the magnitude of the rate observed (Kivekäs et al., 2016). GR app in the Canadian Arctic varied widely, from 0.2 to $15.3 \mathrm{~nm} \mathrm{~h}^{-1}$ $\left(\bar{x}=4.3 \mathrm{~nm} \mathrm{~h}^{-1}, \sigma=4.1 \mathrm{~nm} \mathrm{~h}^{-1}\right.$; Fig. 7). Still, the range of $\mathrm{GR}_{\text {app }}$ reported here agrees generally with those observed during July and August at land-based coastal Arctic sites. Utqiagvik, Alaska, averaged growth rates of 3.6 and $5.0 \mathrm{~nm} \mathrm{~h}^{-1}$ for July and August (2008-2015), respectively (Kolesar et al., 2017), and measurements in Tiksi, Russia, indicated a range of monthly averaged rates of 2.6$4.8 \mathrm{~nm} \mathrm{~h}^{-1}$ for the July-August time period (2010-2014), depending on how events were classified and segregated (Asmi et al., 2016). A higher-altitude study at Summit, Greenland ( $3200 \mathrm{~m}$ above sea level), during summer 2007 showed four growth events with average GR between 0.09 and $0.3 \mathrm{~nm} \mathrm{~h}^{-1}$ (Ziemba et al., 2010), possibly a result of the distance from sources of condensable vapour. As pointed out in the reports of both the Utqiagivik and Tiksi studies, growth rates observed in the Arctic were similar to those measured in lower-latitude environments (Asmi et al., 2016; Kolesar et al., 2017).

Within specific events summarized in Fig. 7 (starting date/time coded in event identifiers; format: "GMMDD_hhmm"), some evidence for decreasing growth rate with increasing diameter can be observed (e.g., event on 14 August 2016: G0814_1452, G0814_1532, G0814_2119), although modal size and growth rate were not well correlated overall within the 2016 data $\left(r^{2}=0.02\right)$. While some authors have shown that linear trends in growth can be used to evaluate growth rates (Dal Maso et al., 2005; Kolesar et al., 2017), in some cases reported in the present study - particularly those producing large number concentrations - the growth rate slowed over time as particles grew larger. When this was clearly occurring, the event was split into subsections to best classify the apparent growth rates observed in this environment, leading to multiple events with different growth rates and size ranges in Fig. 7. Event periods with growth rates higher than $3 \mathrm{~nm} \mathrm{~h}^{-1}$ were often associated with particle diameters smaller than $50 \mathrm{~nm}$, but a global relationship did not exist (Fig. S2). The range of growth rates of the smallest particles measured in this study is in general agreement with observations at Tiksi, Russia, where some events showed slow growth rates $\left(<1 \mathrm{~nm} \mathrm{~h}^{-1}\right)$, while other events indicated faster growth and larger ultimate particle sizes (Asmi et al., 2016). Simultaneous growth of two or more modes was observed in a variety of cases (e.g., Fig. 4b) and will be discussed in detail in a separate paper.

\subsubsection{Condensation sink}

The CS is represented by the first-order rate constant for the removal of condensable vapour via condensation on existing aerosol particles and is a key parameter when assessing atmospheric aerosol nucleation (Dal Maso et al., 2002; Kulmala et al., 2001; Pirjola et al., 1999). Aerosol particles will nucleate when CS is low, as the energy barrier to nucleation is higher than that for condensation on existing particle sur- 

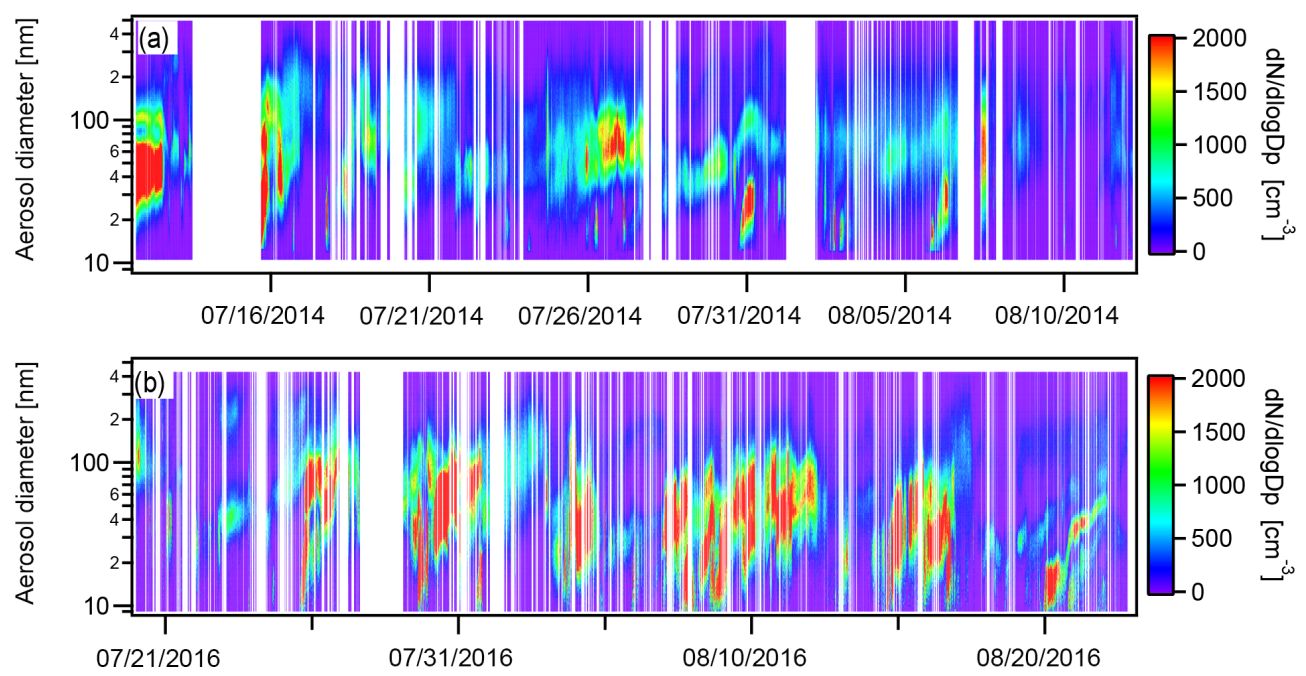

Figure 6. Time series plots of SMPS data from 2014 (a) and 2016 (b) NETCARE campaigns on CCGS Amundsen. The prevalence of ultrafine particle formation and growth events in 2016 is generally visible throughout the campaign and is in stark comparison with the more isolated nucleation and growth events observed in 2014 .

faces. CS measured during the 2014 and 2016 expeditions was within the range of $0.2-10 \mathrm{~h}^{-1}$, with median values of $2.15 \mathrm{~h}^{-1}$ in 2014 and $1.21 \mathrm{~h}^{-1}$ in 2016. During all growth events catalogued in Fig. 7, CS remained on the lower end of the range observed throughout the study but still covered an order of magnitude range of values $\left(0.3-3.45 \mathrm{~h}^{-1}\right)$. CS was uncorrelated with $\mathrm{GR}_{\text {app }}\left(r^{2}=0.007\right)$ and did not appear to have major influence on the occurrence of growth events in the Canadian Arctic during the study periods (Fig. S3). With that noted, total CS was particularly low $\left(<1 \mathrm{~h}^{-1}\right)$ leading up to and during the beginning of both substantial UFP formation events detailed in Fig. 4.

In order to better understand the sizes of particles that accommodate condensable vapour during each expedition, CS was re-calculated using different groups of size bins in Eq. (2), specifically just the size bins that were measured by the SMPS $\left(\mathrm{CS}_{\mathrm{SMPS}} ; d_{\mathrm{p}}<430 \mathrm{~nm}\right)$ and just the SMPS size bins for $d_{\mathrm{p}}<100 \mathrm{~nm}\left(\mathrm{CS}_{100}\right)$. For $95 \%$ of the observations in 2016, greater than $65 \%$ of CS was derived from particles with $d_{\mathrm{p}}<430 \mathrm{~nm}$ (Fig. 8a). Coarse particle sources like sea spray, therefore, did not appear to have substantial influence on the degree to which conditions were conducive to nucleation in the summertime Canadian Arctic. In fact, the UFP formation event shown in Fig. 4b was initially observed simultaneously with primary marine aerosol production that brought the contribution of particles with $d_{\mathrm{p}}>500 \mathrm{~nm}$ to CS up to $\sim 50 \%$, but the absolute value of CS was still at the low value of approximately $1.4 \mathrm{~h}^{-1}$, as discussed previously. The $\mathrm{CS}_{100}$, in contrast, was often a substantial fraction of the total condensation sink in 2016 (Fig. 8b), with $\mathrm{CS}_{100} / \mathrm{CS}_{\text {TOT }}>0.5$ for $\sim 25 \%$ of observations. This indicates that the nucleating and/or growing particles were an important contributor to total CS during that season and may account for the prevalence of UFP growth observed especially often in 2016, as the capacity for larger particles to accommodate condensable material was low and variable (Fig. 8b). Particles with $d_{\mathrm{p}}<100 \mathrm{~nm}$ contributed less to total CS in 2014, as UFP formation was much less frequent; only one main peak in Fig. $8 \mathrm{~b}$ can be observed.

Comparing the normalized cumulative distribution of total CS for the 2014 and 2016 study periods with published median values from continental locations (Donahue et al., 2016; Westervelt et al., 2013), the Canadian Arctic marine environment exhibited a median CS that was a factor of 3-6 lower than that observed in Hyytiälä, Finland (median CS of $6.3 \mathrm{~h}^{-1}$ ), a heavily studied remote boreal forest location where nucleation is commonly observed (Kulmala et al., 2014). The range in CS from the present study overlaps with the lower end of the ranges observed during the summer at Utqiagivik, Alaska (Kolesar et al., 2017), Zeppelin station near Ny-Ålesund, Svalbard (Giamarelou et al., 2016), and Mace Head, Ireland (Dal Maso et al., 2002) (Fig. 8c). Prior studies in the Arctic and elsewhere have noted that low CS was important for UFP formation to occur in the Arctic (Chang et al., 2011; Engvall et al., 2008a; Leaitch et al., 2013) although the importance of low CS was often contrasted with the highly polluted "Arctic haze" period in the spring season. The present study suggests that relatively low CS values in the summertime Canadian Arctic marine boundary layer are more common and widespread than other locales - particularly those at lower latitudes - and therefore may not be a factor that directly limits the formation of UFP in this region. 


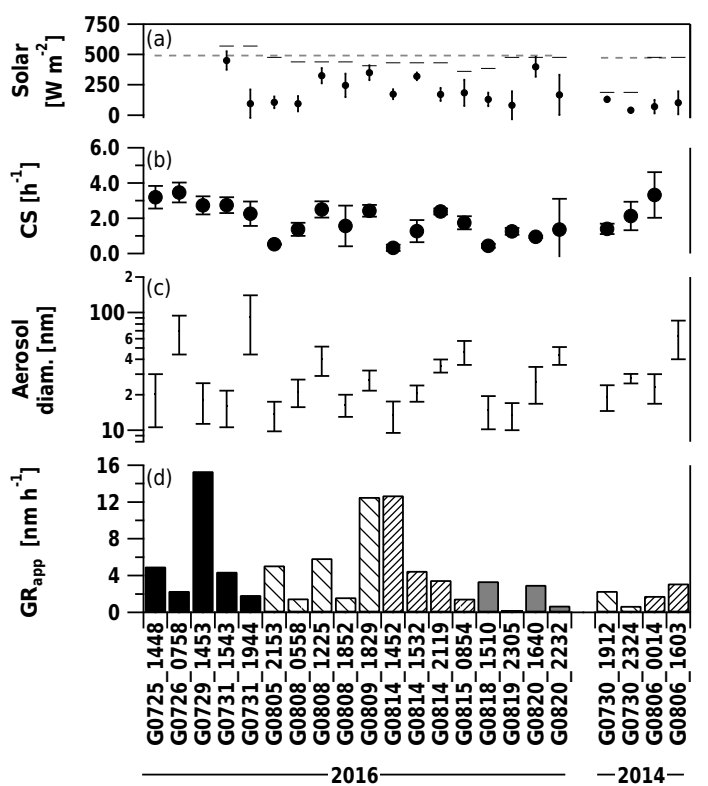

Figure 7. Summary of parameters commonly relevant to ultrafine particle formation and growth in the atmosphere. In the top panel, filled circles represent the mean insolation $( \pm 1 \sigma)$ for the period over which growth was measured, the horizontal dash marker is the maximum insolation for day on which the event began, and the horizontal grey dashed line is the average maximum incident shortwave radiation for days on which an event was not observed during each expedition. The second panel shows the condensation sink $(\mathrm{CS} ; \pm 1 \sigma)$ during each period in which growth rate was measured. The third panel shows the particle size range over which growth was observed or quantified. The bottom panel shows the apparent growth rate of particles $\left(\mathrm{GR}_{\mathrm{app}}\right)$, measured as the rate of change in the modal diameter. The date and UTC time of the beginning of each event are coded within each event label, and the events are shaded to group by region.

\subsection{Environmental conditions}

In order to provide context to the observations from each of the two expeditions, a suite of atmospheric and oceanic conditions was compiled and is shown in Figs. 9-11. In this study, only expedition-wide analysis of the data, rather than temporal correlations or finer-scale analysis, has been presented in light of the complex relationships expected between basic environmental parameters and the formation of UFP in the atmosphere

\subsubsection{Atmospheric conditions}

Ambient air temperature and relative humidity frequency distributions illustrate basic similarities between the two expeditions, owing to the consistent time of year and geographical extent of the measurements, although some slight differences exist. The 2016 expedition experienced a wider range of ambient temperatures (Fig. 9b) with the lowest temperatures (below $0^{\circ} \mathrm{C}$ ) occurring at the northernmost extent of the cruise track $\left(81^{\circ} \mathrm{N}\right.$ latitude) and the warmest temperatures $\left(10-15^{\circ} \mathrm{C}\right)$ occurring mainly in the Queen Maud Gulf region $\left(68^{\circ} \mathrm{N}\right.$ latitude) at the southwest extent of the study area. RH was generally lower in 2016 (Fig. 9d), suggesting that fogs and low clouds may have been less prevalent. This is further supported by the stronger peak in the frequency distribution of daily maximum solar radiation around $400 \mathrm{~W} \mathrm{~m}^{-2}$ in 2016 (Fig. 9a, dashed lines). Studies have suggested that removal of particles in the Arctic summer is strongly coupled to wet scavenging (Browse et al., 2012; Croft et al., 2016b), so the suggestion of more common fogs and low clouds based on the $\mathrm{RH}$ and solar radiation data would support the fact that aerosol concentrations were generally lower in 2014 with UFP formation and growth occurring less often.

Cloudiness in the Arctic for each of the two expeditions was directly compared using monthly MODIS liquid cloud fraction retrievals, using August data from both years. While average liquid cloud fraction in the study region between 2014 and 2016 (within the box in Fig. 10) indicates the lack of an overall difference in cloudiness between 2014 and $2016\left(\bar{x}_{2014}=0.28, \bar{x}_{2016}=0.28\right)$, the difference map of cloud fraction indicates that spatial differences existed, with a range in the per-grid square differences between 2016 and 2014 of -0.3 to 0.3 depending on location (Fig. S3). The geographic distribution of cloud fraction and its difference between 2016 and 2014 within the study region differs to a degree that may help explain differences observed in aerosol concentration and UFP formation or growth, with the largest negative values in Fig. 10c occurring throughout Upper Baffin Bay, Nares Strait, and Queen Maud Gulf where UFP formation and growth was observed frequently in 2016.

Solar radiation is known to drive photochemical reactions in the gas phase which produce low-vapour-pressure compounds that contribute to particle formation and growth (Kulmala et al., 2014; Zhang et al., 2012). Recently, solar radiation has also been suggested to influence the flux of volatile organic compounds to the gas phase in the marine environment through photochemical reactions at the air-sea interface (Brüggemann et al., 2017; Chiu et al., 2017). The average incoming shortwave solar radiation measured during each growth event was always lower than the maximum daily solar radiation (Fig. 7a), since UFP formation was commonly initiated in the afternoon. $\mathrm{GR}_{\text {app }}$ showed moderate positive correlation with solar radiation $\left(r^{2}=0.30\right)$, but only when the highest rates $\left(\mathrm{GR}_{\mathrm{app}}>10 \mathrm{~nm} \mathrm{~h}^{-1}\right)$ were excluded from consideration (Fig. S3). Since the Arctic boundary layer in summer is typically stable (Tjernström et al., 2012), it is likely that high solar radiation enhanced the concentrations of condensable materials in the gas phase, which were concentrated within the boundary layer. A recent report of vertical profiles of UFP in this region showed a maximum in the boundary layer (Burkart et al., 2017), suggesting a source that is associated with the Earth's surface.

In summary, cloud cover can be associated with both wet scavenging of aerosol along with simultaneous dimming of 

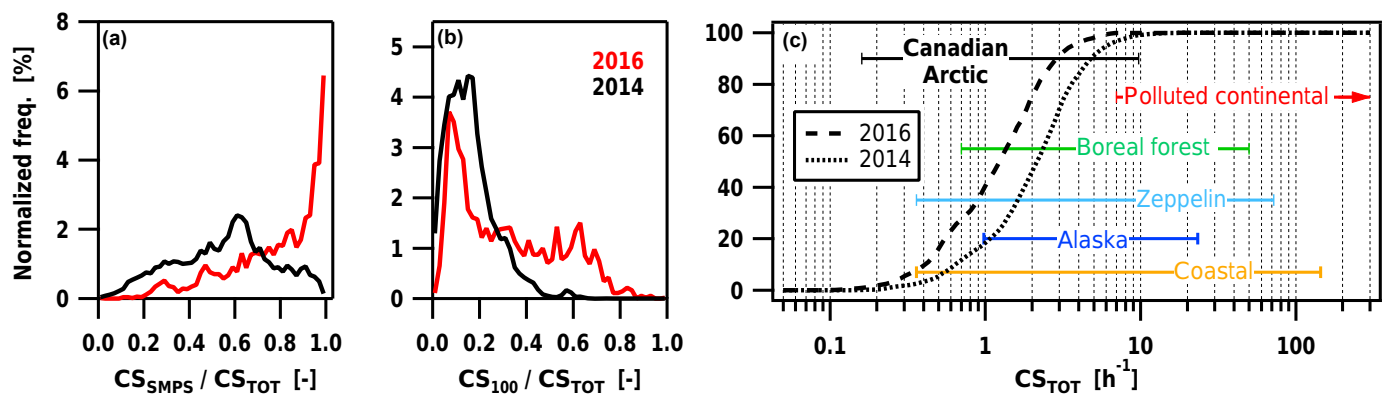

Figure 8. (a) Normalized frequency distribution of the fractional contribution of particles measured by SMPS $\left(\mathrm{CS}_{\mathrm{SMPS}} ; d_{\mathrm{p}}=10-430 \mathrm{~nm}\right)$

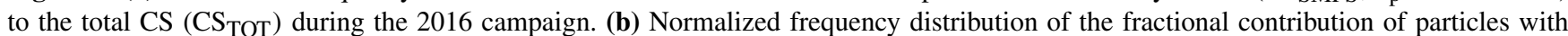
$d_{\mathrm{p}}<100 \mathrm{~nm}\left(\mathrm{CS}_{100}\right)$ to $\mathrm{CS}_{\mathrm{TOT}}$. (c) Normalized cumulative frequency distribution of CS calculated from measured size distributions during the 2014 and 2016 campaigns. Coloured horizontal lines, shown for context, denote ranges of CS from the Canadian Arctic (this study; 1 and $99 \%$ values), a polluted continental site (Po Valley, Italy), a boreal forest site (Hyytiälä, Finland) (Westervelt et al., 2013), a site on the northern coast of Alaska (Utqiagivik (Barrow), summer) (Kolesar et al., 2017), Zeppelin station (near Ny-Ålesund, Svalbard) (Giamarelou et al., 2016), and a coastal location in the North Atlantic (Mace Head, Ireland) (Dal Maso et al., 2002). The upper limit of the polluted continental site is off scale $\left(\sim 2 \times 10^{4} \mathrm{~h}^{-1}\right)$.
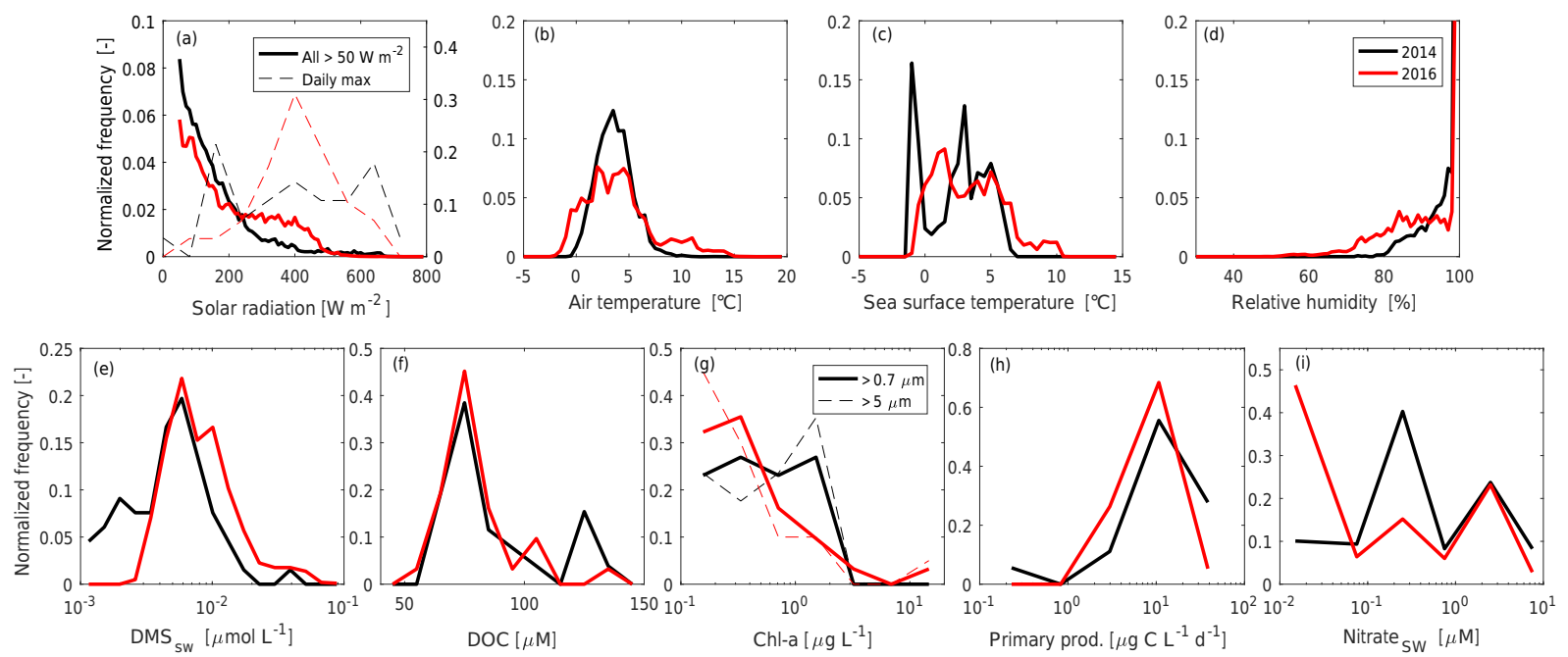

Figure 9. Normalized histograms of environmental parameters measured or sampled aboard CCGS Amundsen in 2014 and 2016. (a) Solar radiation, (b) ambient air temperature, (c) sea surface temperature, (d) atmospheric relative humidity, (e) dimethyl sulfide in surface seawater $\left(\mathrm{DMS}_{\mathrm{sw}}\right)$, (f) dissolved organic carbon (DOC) in surface seawater, (g) chlorophyll $a$ (chl $a$ ) in surface seawater captured on filters of two different porosities, (h) primary productivity in surface seawater, and (i) nitrate in seawater averaged over the top $35 \mathrm{~m}$ of each depth profile.

the planetary boundary layer and surface. While wet scavenging is an important removal mechanism for aerosol in the Arctic summer (Browse et al., 2012; Croft et al., 2016b) and the resulting low CS is important for priming the environment for aerosol nucleation to occur (Dal Maso et al., 2002; Kreidenweis et al., 1991; Pirjola et al., 1999), low solar radiation at the surface resulting from cloud cover may also cause a reduction in the source of precursors for UFP formation and growth. Solar radiation measured aboard CCGS Amundsen in 2016 was greater than in 2014, and when combined with a generally low CS and typically stable Arctic marine boundary layer, one finds that the conditions were overall more conducive to UFP formation in 2016 than in
2014. The source strengths of gas-phase precursors and reactive species, which are generally not well understood in the marine environment, are key remaining factors for explaining interannual differences and regional variability in UFP formation in the Arctic marine environment.

\subsubsection{Oceanic conditions}

Sea ice concentrations in the Canadian Arctic were lower in 2016 than 2014, especially during August. Averaged over the study period, sea ice concentration was approximately $13 \%$ lower in 2016 throughout the Canadian Arctic as a whole relative to 2014, albeit with substantial spatial variability (Fig. 11). The relative daily average differences in sea 

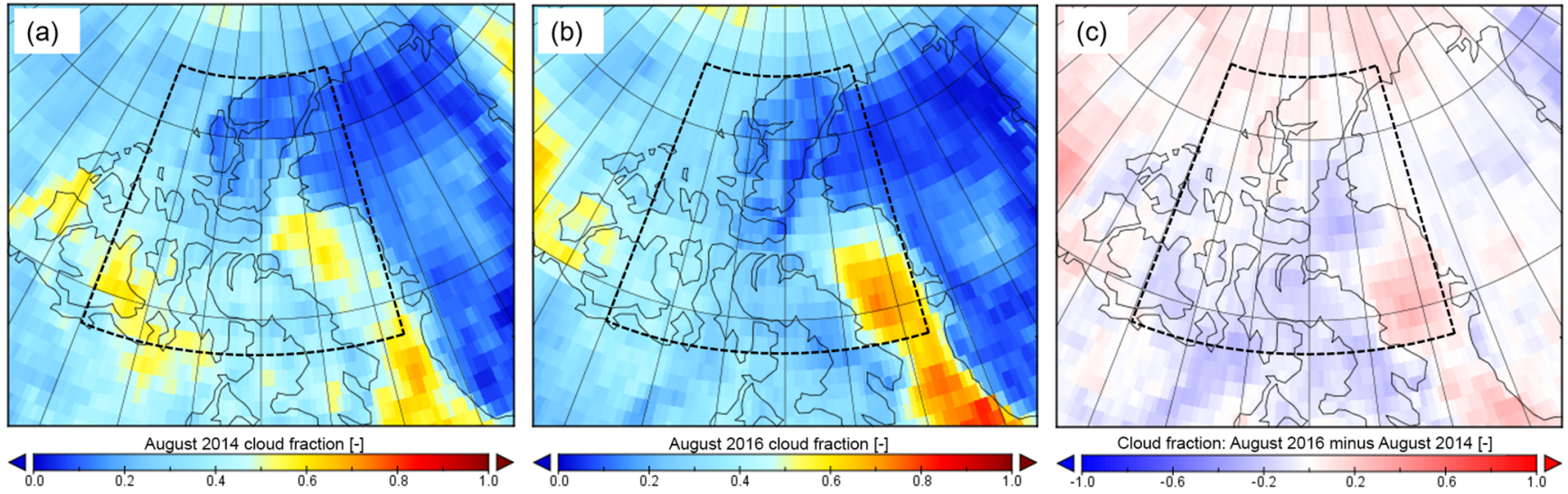

Figure 10. Aqua MODIS retrieval of monthly averaged daily liquid cloud fraction for (a) August 2014, (b) August 2016, and (c) the difference between 2016 and 2014. The dashed black box denotes the area within which the study-area average was computed. Data from NASA/GSFC on a Lambert conformal conic projection.
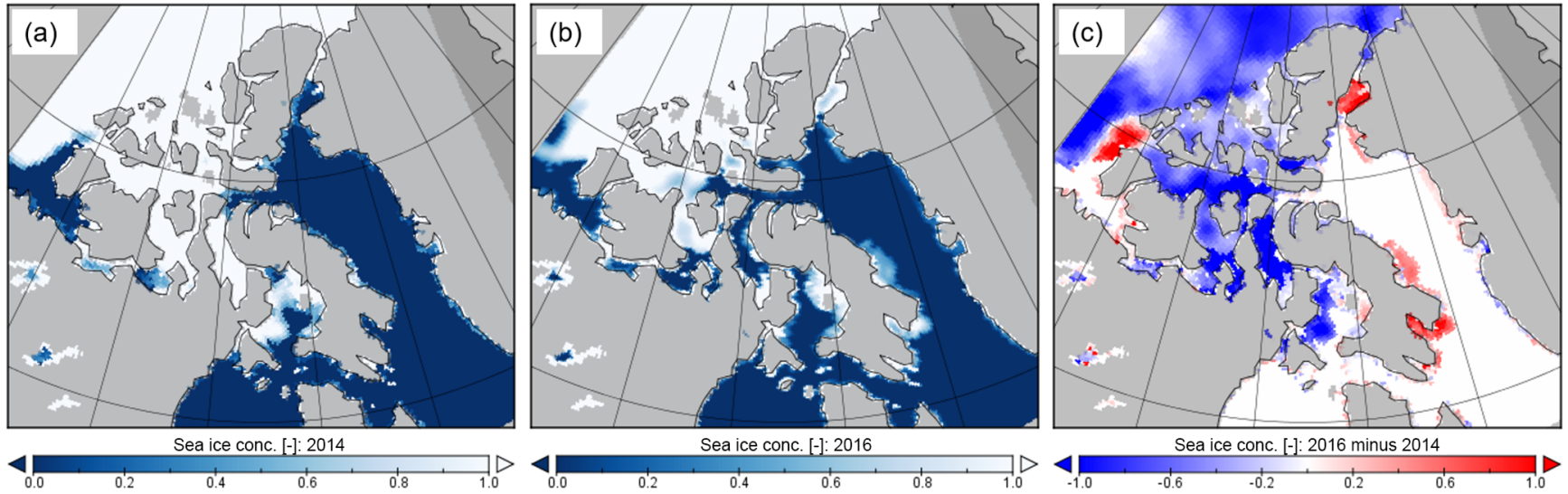

Figure 11. Sea ice concentrations within the Canadian Arctic, plotted for a single example day (1 August): (a) 2014, (b) 2016, and (c) difference between 2016 and 2014. Data from NASA/NSIDC (Maslanik and Stroeve, 1999) on a Lambert conformal conic projection.

ice concentration between 2016 and 2014 (Fig. 12) were between -6 and $+3 \%$ in mid-July, with a steep shift to relative differences between -13 and $-25 \%$ during August. Open water was exposed in 2016 throughout Lancaster Sound, Barrow Strait, Peel Sound, and Queen Maud Gulf (locations west of $\sim 90^{\circ} \mathrm{W}$ longitude). Sea ice coverage was greater in 2016 along the coast of Baffin Island and within the Nares Strait. Ice along Baffin Island in 2016 was discontinuous first-year ice with many open leads and melt ponds mixed with transported icebergs. In Nares Strait, iceberg production by glaciers was a large contributor to sea ice, with open water between them. Despite increased sea ice in two locations where UFP formation and growth was observed, the presence of ice was discontinuous and marine sources of UFP precursors would not have been hindered to a major degree (Loose et al., 2014). Long-term measurements from Alert and Svalbard have shown associations between marine biogenic secondary aerosol tracers (sulfur and nitrogen compounds) and discontinuous sea ice in the Arctic (Dall'Osto et al., 2017b;
Sharma et al., 2012). Recently, decreasing sea ice was also associated with UFP formation and growth (Dall'Osto et al., 2017b). In addition to remotely sensed sea ice coverage, the difference in the amount of time that CCGS Amundsen spent in sea ice between the two expeditions can also be noted in the histograms of sea surface temperature (Fig. 9c), where a distinct local maximum in normalized frequency of measurements just below $0{ }^{\circ} \mathrm{C}$ is notable only in 2014. Since discontinuous ice can lead to greater air-sea exchange of volatile precursors that have the demonstrated ability to form UFP, it is likely that the lower sea ice fraction in 2016 could have contributed to the difference in the frequency of UFP formation and growth observed in this study.

It has long been thought that secondary aerosol formation and its influence on CCN concentrations in the marine environment is associated with the atmospheric chemistry of marine biogenic organic and inorganic precursors (e.g., Charlson et al., 1987; Clarke et al., 1998; Facchini et al., 2008; Fu et al., 2013; O'Dowd et al., 2002; O'Dowd and de Leeuw, 


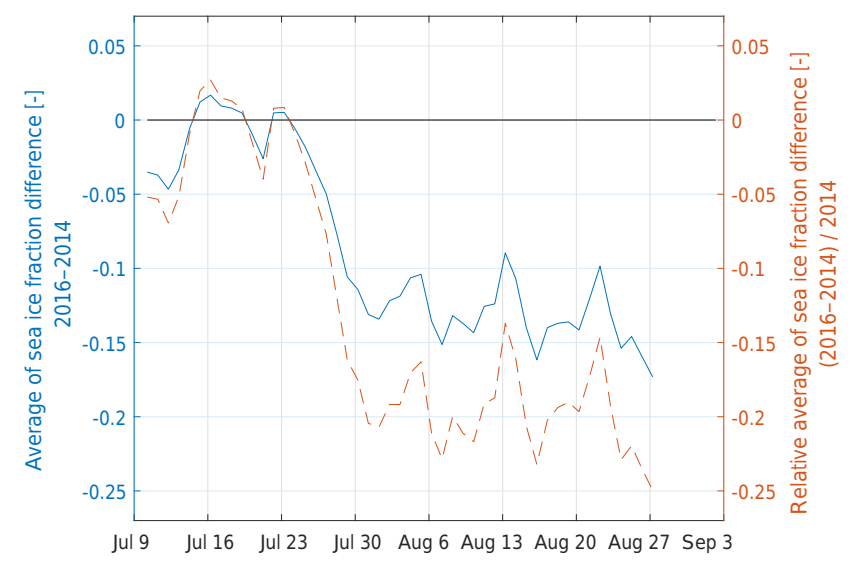

Figure 12. Time-resolved domain average of the difference in sea ice concentration between 2014 and 2016 within the Canadian Arctic (blue solid) and the domain average difference in sea ice normalized by the average 2014 concentration (red dashed; see Supplement). Data from NASA/NSIDC (Maslanik and Stroeve, 1999).

2007). Some assessments have tempered expectations of climate feedback mechanisms to exist in tropical and temperate zones (Heintzenberg et al., 2004; Pirjola et al., 2000; Quinn and Bates, 2011), but evidence for the formation of CCNactive secondary marine aerosol has been reported (Clarke et al., 1998; Dall'Osto et al., 2017b; Facchini et al., 2008; Willis et al., 2016). The prevalence of strong associations between UFP and air mass exposure to open ocean in the Arctic (Dall'Osto et al., 2017b; Sharma et al., 2012) suggests that UFP formation and growth may be more strongly coupled to oceanic biological activity, since summertime conditions are highly favourable for UFP formation (Heintzenberg et al., 2015; Leaitch et al., 2013; Leck and Bigg, 2010; Rempillo et al., 2011; Sharma et al., 2012). In addition, within the Canadian Arctic, the ratio of coastline to open water is relatively large compared to other regions, enhancing the importance of volatile precursor sources at land-ocean boundaries, like seabird colonies (Croft et al., 2016a; Weber et al., 1998) and intertidal zones (O'Dowd et al., 2002; Sipilä et al., 2016).

Emerging research suggests that ecosystem interactions within the surface ocean are more important to air-sea chemical interactions than the state of any single biological variable (Collins et al., 2013; Lee et al., 2015; O’Dowd et al., 2015; Wang et al., 2015). Oceanic measurements of both ecosystem interactions and biological state were analysed to assess the behaviour of microbiota in the surface ocean during the study period. Frequency distributions of different metrics that have been associated with marine microbiological activity are shown in Fig. 9e-h: DMS and PP. While each of these metrics has a different relationship to the broad notion of "marine microbiological activity", taken together they may provide valuable information on the general state of the marine biological system during each expedition. Three of the four aforementioned metrics exhib- ited broadly similar characteristics between the two cruises, with subtle yet discernible differences. DOC concentrations were nearly identical between the two summers; it is possible that DOC concentrations in this region are driven to a substantial degree by physical processes (e.g., ocean mixing) and/or inputs from terrigenous sources (Dittmar and Kattner, 2003; Hansell et al., 2009) rather than just marine biological processes. While $\mathrm{DMS}_{\mathrm{sw}}$ concentrations have a similar modal concentration in the frequency distribution, a larger fraction of the measurements showed concentrations greater than $1 \mathrm{nmol} \mathrm{L}^{-1}$ in 2016 compared with 2014 (Fig. 9e). In most locations, chl $a$, PP, and nitrate skewed lower in 2016 than 2014 (Fig. 9g-i; see also Fig. S5), suggesting that the phytoplankton production season was more advanced and well into the post-bloom phase. This difference is consistent with the greater contribution of small phytoplankton to chl $a$ and may be related to the lower sea ice concentration in 2016. $\mathrm{DMS}_{\mathrm{sw}}$ production results from the enzymatic cleavage of the cellular osmolyte dimethylsulfoniopropionate (DMSP) often found in microalgae at different intracellular levels in relation to phytoplankton species composition (Keller et al., 1989) and oxidative stress (Stefels et al., 2007; Sunda et al., 2002). The breakdown process from DMSP to DMS is performed by certain phytoplankton and is widespread among bacterioplankton (Stefels et al., 2007). Bacterial DMS production may be more particularly important when PP declines towards the later stages of a phytoplankton bloom (Azam et al., 1983). Changes in the chemical and physicochemical properties of marine aerosol have been associated with declining phytoplankton abundance; it is thought that dynamic ecosystem processes, including hydrolytic enzyme interactions with organic matter, are important to aerosol production and composition (Collins et al., 2013; Lee et al., 2015; O’Dowd et al., 2015; Wang et al., 2015). Lower PP, nitrate, and chl $a$ with higher $\mathrm{DMS}_{\mathrm{sw}}$ collectively suggest that the seasonal bloom was in a later phase of development in 2016 compared with 2014, which could be associated with enhanced emissions of trace gases by microbial communities (Carpenter et al., 2012; Schulz and Dickschat, 2007; Shaw et al., 2010), potentially including those that could act as precursors to UFP formation and/or aerosol growth. While the full suite of gases emitted from biologically active oceans is not well understood (although a dependence on community composition has been shown e.g., Colomb et al., 2008), the general understanding that trace gas production can be enhanced by certain biological interactions and productivity (e.g., Leck and Rodhe, 1991; Mäkelä et al., 2002; Shaw et al., 2010) points to an association with increased UFP formation and/or growth, as observed in summer 2016.

It is plausible that the greater retreat of sea ice during 2016 compared with 2014 acted cooperatively with the observed differences in biological activity from the marine biogeochemical analysis provided above. Sea ice margins and under-ice biological communities have been suggested as important contributors to volatile sulfur- and nitrogen- 
containing precursors to UFP formation in polar regions (Dall'Osto et al., 2017a; Levasseur, 2013). Indeed, UFP formation has been observed in the Arctic marginal ice zone and can be correlated with decreasing sea ice concentration over multi-year periods, although the factors driving Arctic UFP formation are still uncertain (Dall'Osto et al., 2017b; Karl et al., 2012; Leck and Bigg, 2010). The enhanced interaction of marginal or fragmented sea ice in 2016 may have contributed to the greater frequency of UFP formation and growth observed. At the same time, a greater retreat of sea ice could have also enhanced or changed the timing of the seasonal phytoplankton bloom in the Canadian Arctic, causing the bloom to be in a more advanced developmental stage at the time of sampling in 2016 compared with 2014. Further study of biosphere-atmosphere interactions at or near the marginal ice zone and/or during the spring melt season may help elucidate mechanistic details that connect sea ice decay with UFP formation in polar regions.

\section{Conclusions}

This study presents detailed number size distribution measurements of aerosol particles in the Canadian Arctic marine boundary layer during two summer seasons, 2014 and 2016. This unique data set highlights the wide spatial extent of UFP in the summertime Arctic and a range in particle number concentrations $\left(d_{\mathrm{p}}>4 \mathrm{~nm}\right)$ that spanned 3 orders of magnitude $\left(10^{1}-10^{4} \mathrm{~cm}^{-3}\right)$. The low background concentrations of aerosol particles in this region are driven by strong scavenging and relatively weak transport from lower latitudes, and those conditions can set the stage for the formation of UFP within the Arctic marine boundary layer, as shown by this and other studies. By combining two seasons of observations aboard CCGS Amundsen over a similar cruise track, this study was able to document conditions which led to sparse observations of UFP formation and growth in 2014 (events on $6 \%$ of measurement days) and more frequent observation of UFP formation and growth events in 2016 (events on $41 \%$ of measurement days). CS in the Canadian Arctic was consistently low $\left(\sim 1-2 \mathrm{~h}^{-1}\right)$ in both summer expeditions compared with other regions. Comparison of environmental conditions between the two seasons of measurements suggests that the generally low CS, coupled with higher solar radiation, a greater fraction of open water (lower sea ice concentration), and the differences in biological activity in the local marine environment, may have individually or collectively contributed to a greater frequency of UFP formation and growth in 2016. Given the general understanding of how meteorological conditions can influence UFP formation and growth (e.g., Engvall et al., 2008a; Heintzenberg et al., 2015; Kulmala et al., 2014), geographic similarities between UFP formation and growth events across the two expeditions stress the potential importance of marine microbial processes on the occurrence and behaviour of such events in the Canadian Arctic. In addition, chemical transport models and other computational tools, in conjunction with observations reported in this study, may lend important insight into the drivers of UFP formation in the Canadian Arctic and may be translatable to other remote locations. At the same time, atmospheric chemistry involving UFP formation and growth in the Arctic is also a key motivation for fundamental studies of biologically modified ocean-atmosphere interactions (Brüggemann et al., 2017; Lee et al., 2015; Prather et al., 2013).

Data availability. NETCARE (Network on Climate and Aerosols: Addressing Key Uncertainties in Remote Canadian Environments, http://www.netcare-project.ca), which organized the field campaigns described in this work, is moving toward a publically available, online data archive. In the meantime, data can be accessed by contacting the principal investigator of the network: Jonathan Abbatt, University of Toronto (jabbatt@ chem.utoronto.ca).

\section{The Supplement related to this article is available online at https://doi.org/10.5194/acp-17-13119-2017- supplement.}

Competing interests. The authors declare that they have no conflict of interest.

Special issue statement. This article is part of the special issue "NETCARE (Network on Aerosols and Climate: Addressing Key Uncertainties in Remote Canadian Environments) (ACP/AMT/BG inter-journal SI)". It is not associated with a conference.

Acknowledgements. This research was conducted by the Network on Climate and Aerosols: Addressing Key Uncertainties in Remote Canadian Environments (NETCARE), funded by the Climate Change and Atmospheric Research (CCAR) program within the Natural Sciences and Engineering Research Council of Canada (NSERC). Funding to authors was also attributed to the National Centers of Excellence (NCE) ArcticNet and NSERC DG program. We thank Alex Lee and Luis Ladino for their help during ship mobilization in 2014, Jennifer Murphy for her assistance during the 2014 expedition, Alexander Moravek for his assistance during the 2016 expedition, Keith Levesque for overall coordination of both ship campaigns on behalf of ArcticNet, Claude Belzile and Mélanie Simard for DOC analysis, and the Canadian Coast Guard officers and crew of CCGS Amundsen for their tireless efforts to make these campaigns possible. We also thank Richard Leaitch for valuable discussions on the subject of this paper.

Edited by: Lynn M. Russell

Reviewed by: two anonymous referees 


\section{References}

Allan, J. D., Williams, P. I., Najera, J., Whitehead, J. D., Flynn, M. J., Taylor, J. W., Liu, D., Darbyshire, E., Carpenter, L. J., Chance, R., Andrews, S. J., Hackenberg, S. C., and McFiggans, G.: Iodine observed in new particle formation events in the Arctic atmosphere during ACCACIA, Atmos. Chem. Phys., 15, 55995609, https://doi.org/10.5194/acp-15-5599-2015, 2015.

AMAP: Arctic Climate Issues 2011: Changes in Arctic Snow, Water, Ice and Permafrost, in SWIPA 2011 Overview Report, Oslo, p. 97, 2012.

Ardyna, M., Gosselin, M., Michel, C., Poulin, M., and Tremblay, J.: Environmental forcing of phytoplankton community structure and function in the Canadian High Arctic: contrasting oligotrophic and eutrophic regions, Mar. Ecol.-Prog. Ser., 442, 3757, https://doi.org/10.3354/meps09378, 2011.

Asmi, E., Kondratyev, V., Brus, D., Laurila, T., Lihavainen, H., Backman, J., Vakkari, V., Aurela, M., Hatakka, J., Viisanen, Y., Uttal, T., Ivakhov, V., and Makshtas, A.: Aerosol size distribution seasonal characteristics measured in Tiksi, Russian Arctic, Atmos. Chem. Phys., 16, 1271-1287, https://doi.org/10.5194/acp16-1271-2016, 2016.

Azam, F., Field, J. G., Graf, J. S., Meyer-Rei, L. A., and Thingstad, F.: The Ecological Role of Water-Column Microbes in the Sea, Mar. Ecol.-Prog. Ser., 10, 257-263, 1983.

Bates, T. S. and Cline, J. D.: The role of the ocean in a regional sulfur cycle, J. Geophys. Res., 90, 9168, https://doi.org/10.1029/JC090iC05p09168, 1985.

Becagli, S., Lazzara, L., Marchese, C., Dayan, U., Ascanius, S. E., Cacciani, M., Caiazzo, L., Di Biagio, C., Di Iorio, T., di Sarra, A., Eriksen, P., Fani, F., Giardi, F., Meloni, D., Muscari, G., Pace, G., Severi, M., Traversi, R., and Udisti, R.: Relationships linking primary production, sea ice melting, and biogenic aerosol in the Arctic, Atmos. Environ., 136, 1-15, https://doi.org/10.1016/j.atmosenv.2016.04.002, 2016.

Browse, J., Carslaw, K. S., Arnold, S. R., Pringle, K., and Boucher, O.: The scavenging processes controlling the seasonal cycle in Arctic sulphate and black carbon aerosol, Atmos. Chem. Phys., 12, 6775-6798, https://doi.org/10.5194/acp12-6775-2012, 2012.

Browse, J., Carslaw, K. S., Mann, G. W., Birch, C. E., Arnold, S. R., and Leck, C.: The complex response of Arctic aerosol to sea-ice retreat, Atmos. Chem. Phys., 14, 7543-7557, https://doi.org/10.5194/acp-14-7543-2014, 2014.

Brüggemann, M., Hayeck, N., Bonnineau, C., Pesce, S., Alpert, P. A., Perrier, S., Zuth, C., Hoffmann, T., Chen, J., and George, C.: Interfacial photochemistry of biogenic surfactants: a major source of abiotic volatile organic compounds, Faraday Discuss., 200, 59-74, https://doi.org/10.1039/C7FD00022G, 2017.

Burkart, J., Willis, M. D., Bozem, H., Thomas, J. L., Law, K., Hoor, P., Aliabadi, A. A., Köllner, F., Schneider, J., Herber, A., Abbatt, J. P. D., and Leaitch, W. R.: Summertime observations of elevated levels of ultrafine particles in the high Arctic marine boundary layer, Atmos. Chem. Phys., 17, 5515-5535, https://doi.org/10.5194/acp-17-5515-2017, 2017.

Carpenter, L. J., Archer, S. D., and Beale, R.: Oceanatmosphere trace gas exchange, Chem. Soc. Rev., 41, 6473, https://doi.org/10.1039/c2cs35121h, 2012.

Carslaw, K. S., Lee, L. A., Reddington, C. L., Pringle, K. J., Rap, A., Forster, P. M., Mann, G. W., Spracklen, D. V., Woodhouse,
M. T., Regayre, L. A., and Pierce, J. R.: Large contribution of natural aerosols to uncertainty in indirect forcing, Nature, 503, 67-71, https://doi.org/10.1038/nature12674, 2013.

Cesana, G., Kay, J. E., Chepfer, H., English, J. M., and de Boer, G.: Ubiquitous low-level liquid-containing Arctic clouds: New observations and climate model constraints from CALIPSO-GOCCP, Geophys. Res. Lett., 39, L20804, https://doi.org/10.1029/2012GL053385, 2012.

Chang, R. Y.-W., Sjostedt, S. J., Pierce, J. R., Papakyriakou, T. N., Scarratt, M. G., Michaud, S., Levasseur, M., Leaitch, W. R., and Abbatt, J. P. D.: Relating atmospheric and oceanic DMS levels to particle nucleation events in the Canadian Arctic, J. Geophys. Res., 116, D00S03, https://doi.org/10.1029/2011JD015926, 2011.

Charlson, R. J., Lovelock, J. E., Andreae, M. O., and Warren, S. G.: Oceanic phytoplankton, atmospheric sulphur, cloud albedo and climate, Nature, 326, 655-661, https://doi.org/10.1038/326655a0, 1987.

Chiu, R., Tinel, L., Gonzalez, L., Ciuraru, R., Bernard, F., George, C., and Volkamer, R.: UV photochemistry of carboxylic acids at the air-sea boundary: A relevant source of glyoxal and other oxygenated VOC in the marine atmosphere, Geophys. Res. Lett., 44, 1079-1087, https://doi.org/10.1002/2016GL071240, 2017.

Clarke, A. D., Varner, J. L., Eisele, F., Mauldin, R. L., Tanner, D., and Litchy, M.: Particle production in the remote marine atmosphere: Cloud outflow and subsidence during ACE 1, J. Geophys. Res.-Atmos., 103, 16397-16409, https://doi.org/10.1029/97JD02987, 1998.

Collins, D. B., Ault, A. P., Moffet, R. C., Ruppel, M. J., CuadraRodriguez, L. A., Guasco, T. L., Corrigan, C. E., Pedler, B. E., Azam, F., Aluwihare, L. I., Bertram, T. H., Roberts, G. C., Grassian, V. H., and Prather, K. A.: Impact of marine biogeochemistry on the chemical mixing state and cloud forming ability of nascent sea spray aerosol, J. Geophys. Res.-Atmos., 118, 85538565, https://doi.org/10.1002/jgrd.50598, 2013.

Colomb, A., Yassaa, N., Williams, J., Peeken, I., and Lochte, K.: Screening volatile organic compounds (VOCs) emissions from five marine phytoplankton species by head space gas chromatography/mass spectrometry (HS-GC/MS), J. Environ. Monitor., 10, 325-330, https://doi.org/10.1039/b715312k, 2008.

Croft, B., Wentworth, G. R., Martin, R. V., Leaitch, W. R., Murphy, J. G., Murphy, B. N., Kodros, J. K., Abbatt, J. P. D., and Pierce, J. R.: Contribution of Arctic seabird-colony ammonia to atmospheric particles and cloud-albedo radiative effect, Nat. Commun., 7, 13444, https://doi.org/10.1038/ncomms13444, 2016a.

Croft, B., Martin, R. V., Leaitch, W. R., Tunved, P., Breider, T. J., D'Andrea, S. D., and Pierce, J. R.: Processes controlling the annual cycle of Arctic aerosol number and size distributions, Atmos. Chem. Phys., 16, 3665-3682, https://doi.org/10.5194/acp16-3665-2016, 2016b.

Dall'Osto, M., Ovadnevaite, J., Paglione, M., Beddows, D. C. S., Ceburnis, D., Cree, C., Cortés, P., Zamanillo, M., Nunes, S. O., Pérez, G. L., Ortega-Retuerta, E., Emelianov, M., Vaqué, D., Marrasé, C., Estrada, M., Montserrat Sala, M., Vidal, M., Fitzsimons, M. F., Beale, R., Airs, R., Rinaldi, M., Decesari, S., Facchini, M. C., Harrison, R. M., O’Dowd, C., and Simó, R.: Antarctic sea ice region as a source of biogenic organic nitrogen in aerosols, Sci. Rep., 7, 6047, https://doi.org/10.1038/s41598-01706188-x, 2017a. 
Dall'Osto, M., Beddows, D. C. S., Tunved, P., Krejci, R., Ström, J., Hansson, H.-C., Yoon, Y. J., Park, K.-T., Becagli, S., Udisti, R., Onasch, T., O’Dowd, C. D., Simó, R., and Harrison, R. M.: Arctic sea ice melt leads to atmospheric new particle formation, Sci. Rep., 7, 3318, https://doi.org/10.1038/s41598-017-03328-1, 2017b.

Dal Maso, M., Kulmala, M., Lehtinen, K. E. J., Mäkelä, J. M., Aalto, P., and O'Dowd, C. D.: Condensation and coagulation sinks and formation of nucleation mode particles in coastal and boreal forest boundary layers, J. Geophys. Res., 107, 8097, https://doi.org/10.1029/2001JD001053, 2002.

Dal Maso, M., Kulmala, M., Riipinen, I., Wagner, R., Hussein, T., Aalto, P. P., and Lehtinen, K. E. J.: Formation and growth of fresh atmospheric aerosols: Eight years of aerosol size distribution data from SMEAR II, Hyytiälä, Finland, Boreal Environ. Res., 10, 323-336, 2005.

Dittmar, T. and Kattner, G.: The biogeochemistry of the river and shelf ecosystem of the Arctic Ocean: a review, Mar. Chem., 83, 103-120, https://doi.org/10.1016/S0304-4203(03)00105-1, 2003

Donahue, N. M., Posner, L. N., Westervelt, D. M., Li, Z., Shrivastava, M., Presto, A. A., Sullivan, R. C., Adams, P. J., Pandis, S. N., and Robinson, A. L.: Where Did This Particle Come From? Sources of Particle Number and Mass for Human Exposure Estimates, in Airborne Particulate Matter: Sources, Atmospheric Processes, and Health, 35-71, 2016.

Engvall, A.-C., Krejci, R., Ström, J., Treffeisen, R., Scheele, R., Hermansen, O., and Paatero, J.: Changes in aerosol properties during spring-summer period in the Arctic troposphere, Atmos. Chem. Phys., 8, 445-462, https://doi.org/10.5194/acp-8445-2008, 2008a.

Engvall, A.-C., Krejci, R., Strom, J., Minikin, A., Treffeisen, R., Stohl, A., and Herber, A.: In-situ airborne observations of the microphysical properties of the Arctic tropospheric aerosol during late spring and summer, Tellus B, 60, 392-404, https://doi.org/10.1111/j.1600-0889.2008.00348.x, 2008b.

Facchini, M. C., Decesari, S., Rinaldi, M., Carbone, C., Finessi, E., Mircea, M., Fuzzi, S., Moretti, F., Tagliavini, E., Ceburnis, D., and O'Dowd, C. D.: Important Source of Marine Secondary Organic Aerosol from Biogenic Amines, Environ. Sci. Technol., 42, 9116-9121, https://doi.org/10.1021/es8018385, 2008.

Ferek, R. J., Hobbs, P. V., Radke, L. F., Herring, J. A., Sturges, W. T., and Cota, G. F.: Dimethyl sulfide in the Arctic atmosphere, J. Geophys. Res., 100, 26093, https://doi.org/10.1029/95JD02374, 1995.

Fu, P. Q., Kawamura, K., Chen, J., Charrière, B., and Sempéré, R.: Organic molecular composition of marine aerosols over the Arctic Ocean in summer: contributions of primary emission and secondary aerosol formation, Biogeosciences, 10, 653-667, https://doi.org/10.5194/bg-10-653-2013, 2013.

Garrett, T. J., Zhao, C., Dong, X., Mace, G. G., and Hobbs, P. V.: Effects of varying aerosol regimes on lowlevel Arctic stratus, Geophys. Res. Lett., 31, L17105, https://doi.org/10.1029/2004GL019928, 2004.

Ghahremaninezhad, R., Norman, A.-L., Abbatt, J. P. D., Levasseur, M., and Thomas, J. L.: Biogenic, anthropogenic and sea salt sulfate size-segregated aerosols in the Arctic summer, Atmos. Chem. Phys., 16, 5191-5202, https://doi.org/10.5194/acp16-5191-2016, 2016.
Giamarelou, M., Eleftheriadis, K., Nyeki, S., Tunved, P., Torseth, K., and Biskos, G.: Indirect evidence of the composition of nucleation mode atmospheric particles in the high Arctic, J. Geophys. Res.-Atmos., 121, 965-975, https://doi.org/10.1002/2015JD023646, 2016.

Grasshoff, K., Kremling, K., and Ehrhardt, M.: Methods of Seawater Analysis, 3rd Edn., John Wiley and Sons, New York, 2009.

Hansell, D., Carlson, C., Repeta, D., and Schlitzer, R.: Dissolved Organic Matter in the Ocean: A Controversy Stimulates New Insights, Oceanography, 22, 202-211, https://doi.org/10.5670/oceanog.2009.109, 2009.

Hegg, D. A., Covert, D. S., Jonsson, H. H., and Woods, R. K.: A simple relationship between cloud drop number concentration and precursor aerosol concentration for the regions of Earth's large marine stratocumulus decks, Atmos. Chem. Phys., 12, 1229-1238, https://doi.org/10.5194/acp-12-1229-2012, 2012.

Heintzenberg, J. and Leck, C.: Seasonal variation of the atmospheric aerosol near the top of the marine boundary layer over Spitsbergen related to the Arctic sulphur cycle, Tellus B, 46, 5267, https://doi.org/10.1034/j.1600-0889.1994.00005.x, 1994.

Heintzenberg, J., Birmili, W., Wiedensohler, A., Nowak, A., and Tuch, T.: Structure, variability and persistence of the submicrometre marine aerosol, Tellus B, 56, 357-367, https://doi.org/10.1111/j.1600-0889.2004.00115.x, 2004.

Heintzenberg, J., Leck, C., and Tunved, P.: Potential source regions and processes of aerosol in the summer Arctic, Atmos. Chem. Phys., 15, 6487-6502, https://doi.org/10.5194/acp-156487-2015, 2015.

Intrieri, J. M., Shupe, M. D., Uttal, T., and McCarty, B. J.: An annual cycle of Arctic cloud characteristics observed by radar and lidar at SHEBA, J. Geophys. Res., 107, 8030, https://doi.org/10.1029/2000JC000423, 2002a.

Intrieri, J. M., Fairall, C. W., Shupe, M. D., Persson, P. O. G., Andreas, E. L., Guest, P. S., and Moritz, R. E.: An annual cycle of Arctic surface cloud forcing at SHEBA, J. Geophys. Res., 107, 8039, https://doi.org/10.1029/2000JC000439, 2002b.

Karl, M., Leck, C., Gross, A., and Pirjola, L.: A study of new particle formation in the marine boundary layer over the central Arctic Ocean using a flexible multicomponent aerosol dynamic model, Tellus B, 64, 17158, https://doi.org/10.3402/tellusb.v64i0.17158, 2012.

Keller, M. D., Bellows, W. K., and Guillard, R. R. L.: Dimethyl Sulfide Production in Marine Phytoplankton, in Biogenic Sulfur in the Environment, ACS Symposium Series No. 393, edited by: Saltzmann, E. S. and Cooper, W. J., 167-182, 1989.

Kivekäs, N., Carpman, J., Roldin, P., Leppä, J., O'Connor, E., Kristensson, A., and Asmi, E.: Coupling an aerosol box model with one-dimensional flow: a tool for understanding observations of new particle formation events, Tellus B, 68, 29706, https://doi.org/10.3402/tellusb.v68.29706, 2016.

Knap, A., Michaels, A., Close, A., Ducklow, H., and Dickson, A.: Protocols for the Joint Global Ocean Flux Study (JGOFS) Core Measurements, in JGOFS Rep No. 19. Reprint of the IOC Manuals and Guides No. 29, UNESCO Intergovernmental Oceanographic Commission, Bergen, Norway, available from: http:// unesdoc.unesco.org/images/0009/000997/099739eo.pdf (last access: 28 April 2017), p. 170, 1996.

Kolesar, K. R., Cellini, J., Peterson, P. K., Jefferson, A., Tuch, T., Birmili, W., Wiedensohler, A., and Pratt, K. A.: Effect of Prudhoe 
Bay emissions on atmospheric aerosol growth events observed in Utqiagvik (Barrow), Alaska, Atmos. Environ., 152, 146-155, https://doi.org/10.1016/j.atmosenv.2016.12.019, 2017.

Kreidenweis, S. M., Penner, J. E., Yin, F., and Seinfeld, J. H.: The effects of dimethylsulfide upon marine aerosol concentrations, Atmos. Environ., 25, 2501-2511, https://doi.org/10.1016/09601686(91)90166-5, 1991.

Kulmala, M., Dal Maso, M., Mäkelä, J. M., Pirjola, L., Väkevä, M., Aalto, P., Miikkulainen, P., Hämeri, K., and O’Dowd, C. D.: On the formation, growth and composition of nucleation mode particles, Tellus, 53, 479-490, 2001.

Kulmala, M., Petäjä, T., Ehn, M., Thornton, J., Sipilä, M., Worsnop, D. R., and Kerminen, V.-M.: Chemistry of Atmospheric Nucleation: On the Recent Advances on Precursor Characterization and Atmospheric Cluster Composition in Connection with Atmospheric New Particle Formation, Annu. Rev. Phys. Chem., 65, 21-37, https://doi.org/10.1146/annurev-physchem-040412$110014,2014$.

Law, K. S. and Stohl, A.: Arctic Air Pollution: Origins and Impacts, Science, 315, 1537-1540, https://doi.org/10.1126/science.1137695, 2007.

Leaitch, W. R., Sharma, S., Huang, L., Toom-Sauntry, D., Chivulescu, A., Macdonald, A. M., von Salzen, K., Pierce, J. R., Bertram, A. K., Schroder, J. C., Shantz, N. C., Chang, R. Y.-W., and Norman, A.-L.: Dimethyl sulfide control of the clean summertime Arctic aerosol and cloud, Elem. Sci. Anthr., 1, 000017, https://doi.org/10.12952/journal.elementa.000017, 2013.

Leaitch, W. R., Korolev, A., Aliabadi, A. A., Burkart, J., Willis, M. D., Abbatt, J. P. D., Bozem, H., Hoor, P., Köllner, F., Schneider, J., Herber, A., Konrad, C., and Brauner, R.: Effects of $20-100 \mathrm{~nm}$ particles on liquid clouds in the clean summertime Arctic, Atmos. Chem. Phys., 16, 11107-11124, https://doi.org/10.5194/acp-16-11107-2016, 2016.

Leck, C. and Bigg, E. K.: Biogenic particles in the surface microlayer and overlaying atmosphere in the central Arctic Ocean during summer, Tellus B, 57, 305-316, https://doi.org/10.1111/j.1600-0889.2005.00148.x, 2005.

Leck, C. and Bigg, E. K.: New Particle Formation of Marine Biological Origin, Aerosol Sci. Tech., 44, 570-577, https://doi.org/10.1080/02786826.2010.481222, 2010.

Leck, C. and Persson, C.: Seasonal and short-term variability in dimethyl sulfide, sulfur dioxide and biogenic sulfur and sea salt aerosol particles in the arctic marine boundary layer during summer and autumn, Tellus B, 48, 272-299, https://doi.org/10.1034/j.1600-0889.48.issue2.1.x, 1996.

Leck, C. and Rodhe, H.: Emissions of marine biogenic sulfur to the atmosphere of northern Europe, J. Atmos. Chem., 12, 63-86, https://doi.org/10.1007/BF00053934, 1991.

Lee, C., Sultana, C. M., Collins, D. B., Santander, M. V., Axson, J. L., Malfatti, F., Cornwell, G. C., Grandquist, J. R., Deane, G. B., Stokes, M. D., Azam, F., Grassian, V. H., and Prather, K. A.: Advancing Model Systems for Fundamental Laboratory Studies of Sea Spray Aerosol Using the Microbial Loop, J. Phys. Chem. A, 119, 8860-8870, https://doi.org/10.1021/acs.jpca.5b03488, 2015.

Levasseur, M.: Impact of Arctic meltdown on the microbial cycling of sulphur, Nat. Geosci., 6, 691-700, https://doi.org/10.1038/ngeo1910, 2013.
Lizotte, M., Levasseur, M., Michaud, S., Scarratt, M. G., Merzouk, A., Gosselin, M., Pommier, J., Rivkin, R. B., and Kiene, R. P.: Macroscale patterns of the biological cycling of dimethylsulfoniopropionate (DMSP) and dimethylsulfide (DMS) in the Northwest Atlantic, Biogeochemistry, 110, 183-200, https://doi.org/10.1007/s10533-011-9698-4, 2012.

Loose, B., McGillis, W. R., Perovich, D., Zappa, C. J., and Schlosser, P.: A parameter model of gas exchange for the seasonal sea ice zone, Ocean Sci., 10, 17-28, https://doi.org/10.5194/os-10-17-2014, 2014.

Lubin, D. and Vogelmann, A.: Observational quantification of a total aerosol indirect effect in the Arctic, Tellus B, 62, 181-189, https://doi.org/10.1111/j.1600-0889.2010.00460.x, 2010.

Mäkelä, J. M., Hoffmann, T., Holzke, C., Väkevä, M., Suni, T., Mattila, T., Aalto, P. P., Tapper, U., Kauppinen, E. I., and O’Dowd, C. D.: Biogenic iodine emissions and identification of end-products in coastal ultrafine particles during nucleation bursts, J. Geophys. Res., 107, 8110, https://doi.org/10.1029/2001JD000580, 2002.

Maslanik, J. and Stroeve, J.: Near-Real-Time DMSP SSMIS Daily Polar Gridded Sea Ice Concentrations, Version 1 [updated daily], NASA Natl. Snow Ice Data Cent. Distrib. Act. Arch. Cent., https://doi.org/10.5067/U8C09DWVX9LM, 1999.

Moore, R. H., Karydis, V. A., Capps, S. L., Lathem, T. L., and Nenes, A.: Droplet number uncertainties associated with $\mathrm{CCN}$ : an assessment using observations and a global model adjoint, Atmos. Chem. Phys., 13, 4235-4251, https://doi.org/10.5194/acp13-4235-2013, 2013.

Mungall, E. L., Croft, B., Lizotte, M., Thomas, J. L., Murphy, J. G., Levasseur, M., Martin, R. V., Wentzell, J. J. B., Liggio, J., and Abbatt, J. P. D.: Dimethyl sulfide in the summertime Arctic atmosphere: measurements and source sensitivity simulations, Atmos. Chem. Phys., 16, 6665-6680, https://doi.org/10.5194/acp16-6665-2016, 2016.

Mungall, E. L., Abbatt, J. P. D., Wentzell, J. J. B., Lee, A. K. Y., Thomas, J. L., Blais, M., Gosselin, M., Miller, L. A., Papakyriakou, T., Willis, M. D., and Liggio, J.: A novel source of oxygenated volatile organic compounds in the summertime marine Arctic boundary layer, P. Natl. Acad. Sci. USA, 114, 6203-6208, https://doi.org/10.1073/pnas.1620571114, 2017.

Nguyen, Q. T., Glasius, M., Sørensen, L. L., Jensen, B., Skov, H., Birmili, W., Wiedensohler, A., Kristensson, A., Nøjgaard, J. K., and Massling, A.: Seasonal variation of atmospheric particle number concentrations, new particle formation and atmospheric oxidation capacity at the high Arctic site Villum Research Station, Station Nord, Atmos. Chem. Phys., 16, 11319-11336, https://doi.org/10.5194/acp-16-11319-2016, 2016.

O’Dowd, C., Ceburnis, D., Ovadnevaite, J., Bialek, J., Stengel, D. B., Zacharias, M., Nitschke, U., Connan, S., Rinaldi, M., Fuzzi, S., Decesari, S., Facchini, M. C., Marullo, S., Santoleri, R., Dell'Anno, A., Corinaldesi, C., Tangherlini, M., and Danovaro, R.: Connecting marine productivity to sea-spray via nanoscale biological processes: Phytoplankton Dance or Death Disco?, Sci. Rep., 5, 14883, https://doi.org/10.1038/srep14883, 2015.

O'Dowd, C. D. and de Leeuw, G.: Marine aerosol production: a review of the current knowledge, Philos. Tr. R. Soc.-S. A, 365, 1753-1774, https://doi.org/10.1098/rsta.2007.2043, 2007.

O’Dowd, C. D., Jimenez, J. L., Bahreini, R., Flagan, R. C., Seinfeld, J. H., Hämeri, K., Pirjola, L., Kulmala, M., Jennings, S. G., and Hoffmann, T.: Marine aerosol forma- 
tion from biogenic iodine emissions, Nature, 417, 632-636, https://doi.org/10.1038/nature00775, 2002.

Parsons, T. R., Maita, Y., and Lalli, C. M.: A manual of chemical and biological methods for seawater analysis, Pergamon Press, Oxford, 1984.

Pirjola, L., Kulmala, M., Wilck, R. M., Bischoff, S. A., Stratmann, F., and Otto, E.: Formation of Sulphuric Acid Aerosols and Cloud Condensation Nuclei: An Expression for Significant Nucleation and Model Comparison, J. Aerosol Sci., 30, 1079-1094, https://doi.org/10.1016/S0021-8502(98)00776-9, 1999.

Pirjola, L., O’Dowd, C. D., Brooks, I. M., and Kulmala, M.: Can new particle formation occur in the clean marine boundary layer?, J. Geophys. Res.-Atmos., 105, 26531-26546, https://doi.org/10.1029/2000JD900310, 2000.

Prather, K. A., Bertram, T. H., Grassian, V. H., Deane, G. B., Stokes, M. D., Demott, P. J., Aluwihare, L. I., Palenik, B. P., Azam, F., Seinfeld, J. H., Moffet, R. C., Molina, M. J., Cappa, C. D., Geiger, F. M., Roberts, G. C., Russell, L. M., Ault, A. P., Baltrusaitis, J., Collins, D. B., Corrigan, C. E., Cuadra-Rodriguez, L. A., Ebben, C. J., Forestieri, S. D., Guasco, T. L., Hersey, S. P., Kim, M. J., Lambert, W. F., Modini, R. L., Mui, W., Pedler, B. E., Ruppel, M. J., Ryder, O. S., Schoepp, N. G., Sullivan, R. C., and Zhao, D.: Bringing the ocean into the laboratory to probe the chemical complexity of sea spray aerosol., P. Natl. Acad. Sci. USA, 110, 7550-7555, https://doi.org/10.1073/pnas.1300262110, 2013.

Pruppacher, H. R. and Klett, J. D.: Microphysics of Clouds and Precipitation, Springer, the Netherlands, Dordrecht, 2010.

Quinn, P. K. and Bates, T. S.: The case against climate regulation via oceanic phytoplankton sulphur emissions, Nature, 480, 5156, https://doi.org/10.1038/nature10580, 2011.

Quinn, P. K., Miller, T. L., Bates, T. S., Ogren, J. A., Andrews, E., and Shaw, G. E.: A 3-year record of simultaneously measured aerosol chemical and optical properties at Barrow, Alaska, J. Geophys. Res.-Atmos., 107, 4130, https://doi.org/10.1029/2001JD001248, 2002.

Ramanathan, V., Crutzen, P. J., Kiehl, J. T., and Rosenfeld, D.: Aerosols, Climate, and the Hydrological Cycle, Science, 294, 2119-2124, https://doi.org/10.1126/science.1064034, 2001.

Rempillo, O., Seguin, A. M., Norman, A.-L., Scarratt, M., Michaud, S., Chang, R., Sjostedt, S., Abbatt, J., Else, B., Papakyriakou, T., Sharma, S., Grasby, S., and Levasseur, M.: Dimethyl sulfide air-sea fluxes and biogenic sulfur as a source of new aerosols in the Arctic fall, J. Geophys. Res., 116, D00S04, https://doi.org/10.1029/2011JD016336, 2011.

Schulz, S. and Dickschat, J. S.: Bacterial volatiles: the smell of small organisms, Nat. Prod. Rep., 24, 814-842, https://doi.org/10.1039/b507392h, 2007.

Sharma, S., Chan, E., Ishizawa, M., Toom-Sauntry, D., Gong, S. L., Li, S. M., Tarasick, D. W., Leaitch, W. R., Norman, A., Quinn, P. K., Bates, T. S., Levasseur, M., Barrie, L. A., and Maenhaut, W.: Influence of transport and ocean ice extent on biogenic aerosol sulfur in the Arctic atmosphere, J. Geophys. Res.-Atmos., 117, D12209, https://doi.org/10.1029/2011JD017074, 2012.

Shaw, G. E.: Production of condensation nuclei in clean air by nucleation of $\mathrm{H}_{2} \mathrm{SO}_{4}$, Atmos. Environ., 23, 2841-2846, https://doi.org/10.1016/0004-6981(89)90564-7, 1989.

Shaw, S. L., Gantt, B., and Meskhidze, N.: Production and Emissions of Marine Isoprene and Monoterpenes: A Review, Adv.
Meteorol., 2010, 1-24, https://doi.org/10.1155/2010/408696, 2010.

Simmonds, I.: Comparing and contrasting the behaviour of Arctic and Antarctic sea ice over the 35 year period 1979-2013, Ann. Glaciol., 56, 18-28, https://doi.org/10.3189/2015AoG69A909, 2015.

Sipilä, M., Sarnela, N., Jokinen, T., Henschel, H., Junninen, H., Kontkanen, J., Richters, S., Kangasluoma, J., Franchin, A., Peräkylä, O., Rissanen, M. P., Ehn, M., Vehkamäki, H., Kurten, T., Berndt, T., Petäjä, T., Worsnop, D., Ceburnis, D., Kerminen, V.-M., Kulmala, M., and O’Dowd, C.: Molecular-scale evidence of aerosol particle formation via sequential addition of $\mathrm{HIO}_{3}$, Nature, 537, 532-534, https://doi.org/10.1038/nature19314, 2016.

Smith, S. R., Bourassa, M. A., and Sharp, R. J.: Establishing More Truth in True Winds, J. Atmos. Ocean. Tech., 16, 939-952, https://doi.org/10.1175/15200426(1999)016<0939:EMTITW>2.0.CO;2, 1999.

Stefels, J., Steinke, M., Turner, S., Malin, G., and Belviso, S.: Environmental constraints on the production and removal of the climatically active gas dimethylsulphide (DMS) and implications for ecosystem modelling, Biogeochemistry, 83, 245-275, https://doi.org/10.1007/s10533-007-9091-5, 2007.

Stohl, A.: Characteristics of atmospheric transport into the Arctic troposphere, J. Geophys. Res., 111, D11306, https://doi.org/10.1029/2005JD006888, 2006.

Stroeve, J. C., Serreze, M. C., Holland, M. M., Kay, J. E., Malanik, J., and Barrett, A. P.: The Arctic's rapidly shrinking sea ice cover: a research synthesis, Clim. Change, 110, 1005-1027, https://doi.org/10.1007/s10584-011-0101-1, 2012.

Ström, J., Engvall, A.-C., Delbart, F., Krejci, R., and Treffeisen, R.: On small particles in the Arctic summer boundary layer: observations at two different heights near Ny-Ålesund, Svalbard, Tellus B, 61, 473-482, https://doi.org/10.1111/j.16000889.2008.00412.x, 2009.

Sunda, W., Kieber, D. J., Kiene, R. P., and Huntsman, S.: An antioxidant function for DMSP and DMS in marine algae, Nature, 418, 317-320, https://doi.org/10.1038/nature00851, 2002.

Tang, M. J., Shiraiwa, M., Pöschl, U., Cox, R. A., and Kalberer, M.: Compilation and evaluation of gas phase diffusion coefficients of reactive trace gases in the atmosphere: Volume 2, Diffusivities of organic compounds, pressure-normalised mean free paths, and average Knudsen numbers for gas uptake calculations, Atmos. Chem. Phys., 15, 5585-5598, https://doi.org/10.5194/acp15-5585-2015, 2015.

Tjernström, M., Birch, C. E., Brooks, I. M., Shupe, M. D., Persson, P. O. G., Sedlar, J., Mauritsen, T., Leck, C., Paatero, J., Szczodrak, M., and Wheeler, C. R.: Meteorological conditions in the central Arctic summer during the Arctic Summer Cloud Ocean Study (ASCOS), Atmos. Chem. Phys., 12, 6863-6889, https://doi.org/10.5194/acp-12-6863-2012, 2012.

Tsigaridis, K., Koch, D., and Menon, S.: Uncertainties and importance of sea spray composition on aerosol direct and indirect effects, J. Geophys. Res.-Atmos., 118, 220-235, https://doi.org/10.1029/2012JD018165, 2013.

Tunved, P., Ström, J., and Krejci, R.: Arctic aerosol life cycle: linking aerosol size distributions observed between 2000 and 2010 with air mass transport and precipitation at Zeppelin station, 
Ny-Ålesund, Svalbard, Atmos. Chem. Phys., 13, 3643-3660, https://doi.org/10.5194/acp-13-3643-2013, 2013.

Turner, S. M., Malin, G., Liss, P. S., Harbour, D. S., and Holligan, P. M.: The seasonal variation of dimethyl sulfide and dimethylsulfoniopropionate concentrations in nearshore waters, Limnol. Oceanogr., 33, 364-375, https://doi.org/10.4319/lo.1988.33.3.0364, 1988.

Vaughan, D. G., Comiso, J. C., Allison, I., Carrasco, J., Kaser, G., Kwok, R., Mote, P., Murray, T., Paul, F., Ren, J., Rignot, E., Solomina, O., Steffen, K., and Zhang, T.: Observations: Cryosphere, in Climate Change 2013: The Physical Science Basis. Contribution of Working Group I to the Fifth Assessment Report of the Intergovernmental Panel on Climate Change, edited by: Stocker, T. F., Qin, D., Plattner, G.-K., Tignor, M., Allen, S. K., Boschung, J., Nauels, A., Xia, Y., Bex, V., and Midgley, P. M., 317-382, Cambridge, UK and New York, NY, USA, 2013.

Walsh, J. E. and Chapman, W. L.: Arctic Cloud-RadiationTemperature Associations in Observational Data and Atmospheric Reanalyses, J. Clim., 11, 3030-3045, 1998.

Wang, X., Sultana, C. M., Trueblood, J., Hill, T. C. J., Malfatti, F., Lee, C., Laskina, O., Moore, K. A., Beall, C. M., McCluskey, C. S., Cornwell, G. C., Zhou, Y., Cox, J. L., Pendergraft, M. A., Santander, M. V., Bertram, T. H., Cappa, C. D., Azam, F., DeMott, P. J., Grassian, V. H., and Prather, K. A.: Microbial Control of Sea Spray Aerosol Composition: A Tale of Two Blooms, ACS Cent. Sci., 1, 124-131, https://doi.org/10.1021/acscentsci.5b00148, 2015.

Weber, R. J., McMurry, P. H., Mauldin, L., Tanner, D. J., Eisele, F. L., Brechtel, F. J., Kreidenweis, S. M., Kok, G. L., Schillawski, R. D., and Baumgardner, D.: A study of new particle formation and growth involving biogenic and trace gas species measured during ACE 1, J. Geophys. Res.-Atmos., 103, 16385-16396, https://doi.org/10.1029/97JD02465, 1998.
Wentworth, G. R., Murphy, J. G., Croft, B., Martin, R. V., Pierce, J. R., Côté, J.-S., Courchesne, I., Tremblay, J.-É., Gagnon, J., Thomas, J. L., Sharma, S., Toom-Sauntry, D., Chivulescu, A., Levasseur, M., and Abbatt, J. P. D.: Ammonia in the summertime Arctic marine boundary layer: sources, sinks, and implications, Atmos. Chem. Phys., 16, 1937-1953, https://doi.org/10.5194/acp-16-1937-2016, 2016.

Westervelt, D. M., Pierce, J. R., Riipinen, I., Trivitayanurak, W., Hamed, A., Kulmala, M., Laaksonen, A., Decesari, S., and Adams, P. J.: Formation and growth of nucleated particles into cloud condensation nuclei: model-measurement comparison, Atmos. Chem. Phys., 13, 7645-7663, https://doi.org/10.5194/acp13-7645-2013, 2013.

Wiedensohler, A., Covert, D. S., Swietlicki, E., Aalto, P., Heintzenberg, J., and Leck, C.: Occurrence of an ultrafine particle mode less than $20 \mathrm{~nm}$ in diameter in the marine boundary layer during Arctic summer and autumn, Tellus B, 48, 213-222, https://doi.org/10.1034/j.1600-0889.1996.t01-1-00006.x, 1996.

Willis, M. D., Burkart, J., Thomas, J. L., Köllner, F., Schneider, J., Bozem, H., Hoor, P. M., Aliabadi, A. A., Schulz, H., Herber, A. B., Leaitch, W. R., and Abbatt, J. P. D.: Growth of nucleation mode particles in the summertime Arctic: a case study, Atmos. Chem. Phys., 16, 7663-7679, https://doi.org/10.5194/acp16-7663-2016, 2016.

Zhang, R., Khalizov, A., Wang, L., Hu, M., and Xu, W.: Nucleation and Growth of Nanoparticles in the Atmosphere, Chem. Rev., 112, 1957-2011, https://doi.org/10.1021/cr2001756, 2012.

Ziemba, L. D., Dibb, J. E., Griffin, R. J., Huey, L. G., and Beckman, P.: Observations of particle growth at a remote, Arctic site, Atmos. Environ., 44, 1649-1657, https://doi.org/10.1016/j.atmosenv.2010.01.032, 2010. 